Check for updates

Cite this: RSC Adv., 2017, 7, 28616

Received 20th January 2017 Accepted 18th May 2017

DOI: $10.1039 / \mathrm{c} 7 \mathrm{ra00870h}$

rsc.li/rsc-advances

\section{Triple zirconocene/brønsted acid/CuO cooperative and relay catalysis system for tandem Mannich addition/C-C formative cyclization/oxidation $\uparrow$}

\author{
Yanlong Luo, Huaming Sun, ${ }^{*}$ Weiqiang Zhang, Xiu Wang, Shan Xu, Guofang Zhang, \\ Yajun Jian and Ziwei Gao (D) *
}

A new triple cooperative and relay catalysis system featuring the Mannich addition followed by $\mathrm{C}-\mathrm{C}$ construction and oxydehydrogenation is described. The zirconocene dichloride and trimellitic acid synergic catalysis triggered the Mannich addition and $\mathrm{C}-\mathrm{C}$ bond construction reactions, while $\mathrm{CuO}$ allowed relay catalysis for oxydehydrogenation. This novel strategy demonstrated superior activity for the synthesis of substituted quinolines from commercially available anilines, aldehydes and ketones. The corresponding substituted quinolines were synthesized with 32 examples in 90-96\% yields under mild reaction conditions. A novel zirconocene-Brønsted acid complex, generated in situ and acting as an active catalyst, was validated from the mechanistic studies.

\section{Introduction}

Relay catalysis reactions are the one-pot multi-catalysis cascade reactions in which each catalytic system promotes one type of transformation in a consecutive fashion. The strategy of relay catalysis obviates the requirement of isolation and purification of products resulting from the each independent transformation. More importantly, the advent of one-pot orthogonal relay catalysis reactions made intricate organic syntheses feasible, which were inaccessible and inefficient by the classical step-wise catalysis. However, establishing such processes need to overcome a number of challenging issues, such as the chemo selectivity and the compatibility between the catalytic systems. The combined metal/metal and metal/organo catalyst dual catalysis are potential kinds of relay catalysis that has stimulated intensive interest in recent years. A number of significant reactions have been developed using metal/metal relay catalysis including $\mathrm{Au} / \mathrm{Ni},{ }^{1} \mathrm{Au} / \mathrm{Ag},{ }^{2} \mathrm{Au} / \mathrm{Yb},{ }^{3} \mathrm{Au} / \mathrm{Sc},{ }^{4} \mathrm{Ru} / \mathrm{Pd} / \mathrm{Cu}^{5}$ and $\mathrm{Pd} / \mathrm{Ag} /$ $\mathrm{Bi}^{6}$ catalyst systems. Regarding to the metal/organo relay catalysis, the metal-Brønsted acid based systems have contributed largely. ${ }^{7-12}$ The metal catalysts such as $\mathrm{Au}, \mathrm{Rh}, \mathrm{Pd}, \mathrm{Ag}$ and $\mathrm{Ru}$ are used in combination with a variety of Brønsted acids. In this context, the development of divergent relay catalysis approaches employing new catalysts is highly desirable.

The cascade reactions for the Mannich reaction followed by the $\mathrm{C}-\mathrm{C}$ or $\mathrm{C}-\mathrm{N}$ bond formation are of highly appealing

Key Laboratory of Applied Surface and Colloid Chemistry, MOE School of Chemistry and Chemical Engineering, Shaanxi Normal University, Xi'an 710062, P. R. China. E-mail: hmsun@snnu.edu.cn; zwgao@snnu.edu.cn

$\dagger$ Electronic supplementary information (ESI) available. See DOI: $10.1039 / \mathrm{c} 7 \mathrm{ra} 00870 \mathrm{~h}$
(Scheme 1). This is because such kind of reactions could construct these fundamental bonds of organic molecules in a single step. In literature, two divergent synthetic procedures with such cascade reaction were available. In 2010, Shin ${ }^{13}$ discovered an one pot redox-pinacol-Mannich-Michael cascade reaction leading to the synthesis of 1-aminoindanes and 5,6-

a) The Mannich-Michael cascade reaction: Ref. $^{13}$
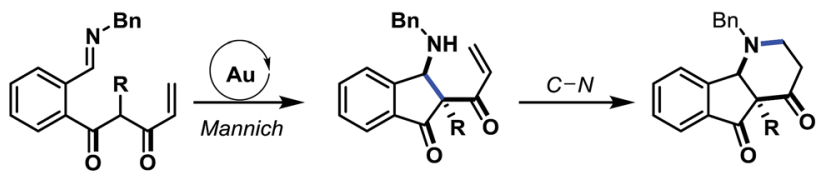

b) Tandem Mannich-C-C bond formation: Ref. ${ }^{14-18}$

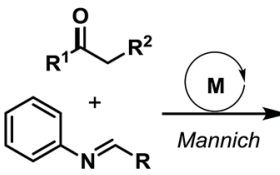<smiles>[R]C(Nc1ccccc1)C([R])C(=O)Nc1ccccc1</smiles><smiles>[R]c1nc2ccccc2c([R])c1[R]</smiles>

c) This work: Mannich-C-C bond construction cascade

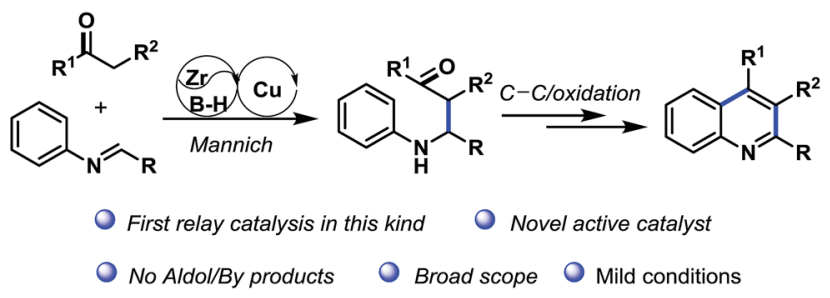

Scheme 1 The reactions involving the Mannich reaction followed by $\mathrm{C}-\mathrm{C} / \mathrm{C}-\mathrm{N}$ bond formation. 
fused azacycles (Scheme 1, eq. a). In this reaction, the gold catalyst rendered the Mannich reaction followed by $\mathrm{C}-\mathrm{N}$ formation in an intramolecular manner. Very recently, $\mathrm{HCl},{ }^{14}$ iodine ${ }^{15} \mathrm{CuCl}_{2},{ }^{16} \mathrm{FeCl}_{3}$ (ref. 17) and AgOTf ${ }^{18}$ catalyzed three components tandem reactions of anilines, aldehydes and ketones for the construction of multi-functionalized quinoline had been reported (Scheme 1, eq. b). This approach undergone intermolecular Mannich reaction followed by intramolecular $\mathrm{C}-\mathrm{C}$ bond formation and oxydehydrogenation.

In this paper, combination with the advantages of cascade reaction integrating the Mannich addition and $\mathrm{C}-\mathrm{C} / \mathrm{C}-\mathrm{N}$ bond construction, the development of new catalytic systems is highly desirable in organic synthesis. Herein, we report an unprecedented cooperative and relay catalysis by zirconocene dichloride, trimellitic acid and $\mathrm{CuO}$ triple catalytic system for the Mannich addition/C-C bond formation/oxydehydrogenation sequence (Scheme 1, eq. c). This triple cooperative and relay catalytic system demonstrated superior activity for synthesis of polysubstituted quinoline from arylamines, aldehydes and ketones under mild condition.

\section{Results and discussion}

We choose aniline, benzaldehyde and methyl pyruvate as substrates to optimize the conditions of cascade Mannich addition, $\mathrm{C}-\mathrm{C}$ bond construction and oxydehydrogenation reaction (Table 1). At first, simple copper salts such as $\mathrm{CuCl}_{2}$, $\mathrm{CuBr}_{2}, \mathrm{Cu}(\mathrm{acac})_{2}, \mathrm{Cu}(\mathrm{OAc})_{2}, \mathrm{CuSO}_{4} \cdot 5 \mathrm{H}_{2} \mathrm{O}, \mathrm{CuO}, \mathrm{Cu}(\mathrm{OTf})_{2}$ and $\mathrm{Cu}\left(\mathrm{ClO}_{4}\right)_{2}$ were used as catalysts in the presence of both $\mathrm{Cp}_{2}$ $\mathrm{TiCl}_{2}$ and $\mathrm{PhCOOH}$ (Table 1, entries 1-8). Among these metal salts, $\mathrm{CuO}$ was found to be the most effective catalyst and the desired product 4 aa was obtained in $31 \%$ yield (Table 1, entry 6). Other commercially available metallocene complexes such as $\mathrm{Cp}^{*} \mathrm{TiCl}_{3}$ and $\mathrm{Cp}_{2} \mathrm{ZrCl}_{2}$ were also used as Lewis acid catalysts for the three-component sequence reactions, which demonstrated that $\mathrm{Cp}_{2} \mathrm{ZrCl}_{2}$ was the best catalyst for this transformation (Table 1, entries 9 and 10). In light of our previous findings that salicylato-titanocene complexes and phenols-titanocene complexes function as organometallic Lewis acids, ${ }^{\mathbf{1 9}}$ a selection of oxygen donor ligands such as phenol and benzenesulfonic acid were evaluated in the reaction of aniline, benzaldehyde and methyl pyruvate (Table 1, entries 11 and 12). None of them provide satisfactory results, which suggested that monofunctional acids were unsuitable for this three-component cascade reaction. With the assistance of $o$-aminobenzoic acid, salicylic acid and phthalic acid, the $\mathrm{Zr}$ catalyst was slightly activated and the tandem reaction afforded desired product with $41 \%, 42 \%$ and $47 \%$ yields, respectively (Table 1, entries $13-$ 15). When glutaric acid and proline were introduced into this triple catalytic system, the desired products were obtained in $29 \%$ and $28 \%$ yields (Table 1 , entries 16 and 17 ). The above results indicated that the aromatic diacids show up higher activity than the aliphatic diacids and amino acids. We hypothesized that higher activity of this catalytic system could be achieved by employing multifunctional acids such as 2aminobenzene-1,4-disulfonic acid, trimellitic acid and 5-sulfosalicylic acid (Table 1, entries 18-20). To our pleased, trimellitic
Table 1 Catalyst and Brønsted acid screening for three-component sequence reaction $^{a}$

\begin{tabular}{|c|c|c|c|}
\hline Entry & Catalyst & Brønsted acid & Yield $^{b}(\%)$ \\
\hline 1 & $\mathrm{Cp}_{2} \mathrm{TiCl}_{2} / \mathrm{CuCl}_{2}$ & $\mathrm{PhCOOH}$ & 30 \\
\hline 2 & $\mathrm{Cp}_{2} \mathrm{TiCl}_{2} / \mathrm{CuBr}_{2}$ & $\mathrm{PhCOOH}$ & 28 \\
\hline 3 & $\mathrm{Cp}_{2} \mathrm{TiCl}_{2} / \mathrm{Cu}(\mathrm{acac})_{2}$ & $\mathrm{PhCOOH}$ & 25 \\
\hline 4 & $\mathrm{Cp}_{2} \mathrm{TiCl}_{2} / \mathrm{Cu}(\mathrm{OAc})_{2}$ & $\mathrm{PhCOOH}$ & 22 \\
\hline 5 & $\mathrm{Cp}_{2} \mathrm{TiCl}_{2} / \mathrm{CuSO}_{4} \cdot 5 \mathrm{H}_{2} \mathrm{O}$ & $\mathrm{PhCOOH}$ & 24 \\
\hline 6 & $\mathrm{Cp}_{2} \mathrm{TiCl}_{2} / \mathrm{CuO}$ & $\mathrm{PhCOOH}$ & 31 \\
\hline 7 & $\mathrm{Cp}_{2} \mathrm{TiCl}_{2} / \mathrm{Cu}(\mathrm{OTf})_{2}$ & $\mathrm{PhCOOH}$ & 26 \\
\hline 8 & $\mathrm{Cp}_{2} \mathrm{TiCl}_{2} / \mathrm{Cu}\left(\mathrm{ClO}_{4}\right)_{2}$ & $\mathrm{PhCOOH}$ & 27 \\
\hline 9 & $\mathrm{Cp}^{*} \mathrm{TiCl}_{3} / \mathrm{CuO}$ & $\mathrm{PhCOOH}$ & 29 \\
\hline 10 & $\mathrm{Cp}_{2} \mathrm{ZrCl}_{2} / \mathrm{CuO}$ & PhCOOH & 34 \\
\hline 11 & $\mathrm{Cp}_{2} \mathrm{ZrCl}_{2} / \mathrm{CuO}$ & $\mathrm{PhOH}$ & 20 \\
\hline 12 & $\mathrm{Cp}_{2} \mathrm{ZrCl}_{2} / \mathrm{CuO}$ & $\mathrm{PhSO}_{3} \mathrm{H}$ & 26 \\
\hline 13 & $\mathrm{Cp}_{2} \mathrm{ZrCl}_{2} / \mathrm{CuO}$ & $\mathrm{Ph}(\mathrm{COOH}) \mathrm{NH}_{2}$ & 41 \\
\hline 14 & $\mathrm{Cp}_{2} \mathrm{ZrCl}_{2} / \mathrm{CuO}$ & $\mathrm{Ph}(\mathrm{COOH}) \mathrm{OH}$ & 42 \\
\hline 15 & $\mathrm{Cp}_{2} \mathrm{ZrCl}_{2} / \mathrm{CuO}$ & $\mathrm{Ph}(\mathrm{COOH})_{2}$ & 47 \\
\hline 16 & $\mathrm{Cp}_{2} \mathrm{ZrCl}_{2} / \mathrm{CuO}$ & $\left(\mathrm{CH}_{2}\right)_{3}(\mathrm{COOH})_{2}$ & 29 \\
\hline 17 & $\mathrm{Cp}_{2} \mathrm{ZrCl}_{2} / \mathrm{CuO}$ & $\mathrm{HNC}_{4} \mathrm{H}_{7} \mathrm{COOH}$ & 28 \\
\hline 18 & $\mathrm{Cp}_{2} \mathrm{ZrCl}_{2} / \mathrm{CuO}$ & $\mathrm{H}_{2} \mathrm{NPh}\left(\mathrm{SO}_{3} \mathrm{H}\right)_{2}$ & 45 \\
\hline 19 & $\mathrm{Cp}_{2} \mathrm{ZrCl}_{2} / \mathrm{CuO}$ & $5-\mathrm{SO}_{3} \mathrm{HPhCOOH}(\mathrm{OH})$ & 48 \\
\hline 20 & $\mathrm{Cp}_{2} \mathrm{ZrCl}_{2} / \mathrm{CuO}$ & $\mathrm{Ph}(\mathrm{COOH})_{3}$ & 54 \\
\hline 21 & $\mathrm{Cp}_{2} \mathrm{ZrCl}_{2} / \mathrm{CuO}$ & $\mathrm{Ph}(\mathrm{COOH})_{3}$ & $88^{c}$ \\
\hline
\end{tabular}

${ }^{a}$ All reactions were conducted using the aniline $(1.0 \mathrm{mmol})$, benzaldehyde $(1.0 \mathrm{mmol})$, methyl pyruvate $(1.0 \mathrm{mmol})$, catalyst (0.05 mmol, $5 \mathrm{~mol} \%)$, Brønsted acid (0.05 mmol, $5 \mathrm{~mol} \%), 50{ }^{\circ} \mathrm{C}, 1 \mathrm{~h}$. ${ }^{b}$ Isolated yields. ${ }^{c} 50{ }^{\circ} \mathrm{C}, 2 \mathrm{~h}$.

acid is the most potent catalyst among the three multifunctional aromatic acids, which promotes the reaction to afford the desired product in 54\% yield, higher than 5-sulfosalicylic acid and 2-aminobenzene-1,4-disulfonic acid. When the reaction time extended to $2 \mathrm{~h}$, the yield increases to $88 \%$, but the yield increased slightly with further extension of the reaction time (Table 1, entry 21). After an extensive screening of the reaction parameters (see the ESI $\dagger$ ), the best yield of 4aa was obtained when reaction was performed in $i$-propanol/water $(3: 1)$ at $60{ }^{\circ} \mathrm{C}$.

With the optimal reaction conditions in hand, we set out to expand the generality and scope of $\mathrm{Cp}_{2} \mathrm{ZrCl}_{2}$, trimellitic acid and $\mathrm{CuO}$ catalyzed three-component cascade reaction. $1 \mathrm{mmol}$ aldehyde, $1.1 \mathrm{mmol}$ of anilines and $1.5 \mathrm{mmol}$ of ketones with 5 $\mathrm{mol} \%$ of $\mathrm{Cp}_{2} \mathrm{ZrCl}_{2}, 5 \mathrm{~mol} \%$ of trimellitic acid, $5 \mathrm{~mol} \%$ of $\mathrm{CuO}$ at $60{ }^{\circ} \mathrm{C}$ for $2 \mathrm{~h}$ were operated as the typical selection. It is found that the reaction proceeded smoothly with aldehydes and aromatic amines bearing either electron-withdrawing or donating groups (Table 2). The substituents with different electron properties has little impact on this transformation, such as anilines containing methyl (4ab), methoxyl (4ac) or fluorous (4ai) group, benzaldehydes with methyl (4ak), $i$-propyl (4al), $t$-butyl (4am) or methoxyl (4ad) group and pyruvate with 
Table 2 Zirconocene dichloride/trimellitic acid/copper oxide catalyzed three components tandem reaction of aldehydes, arylamines and pyruvates ${ }^{a, b}$
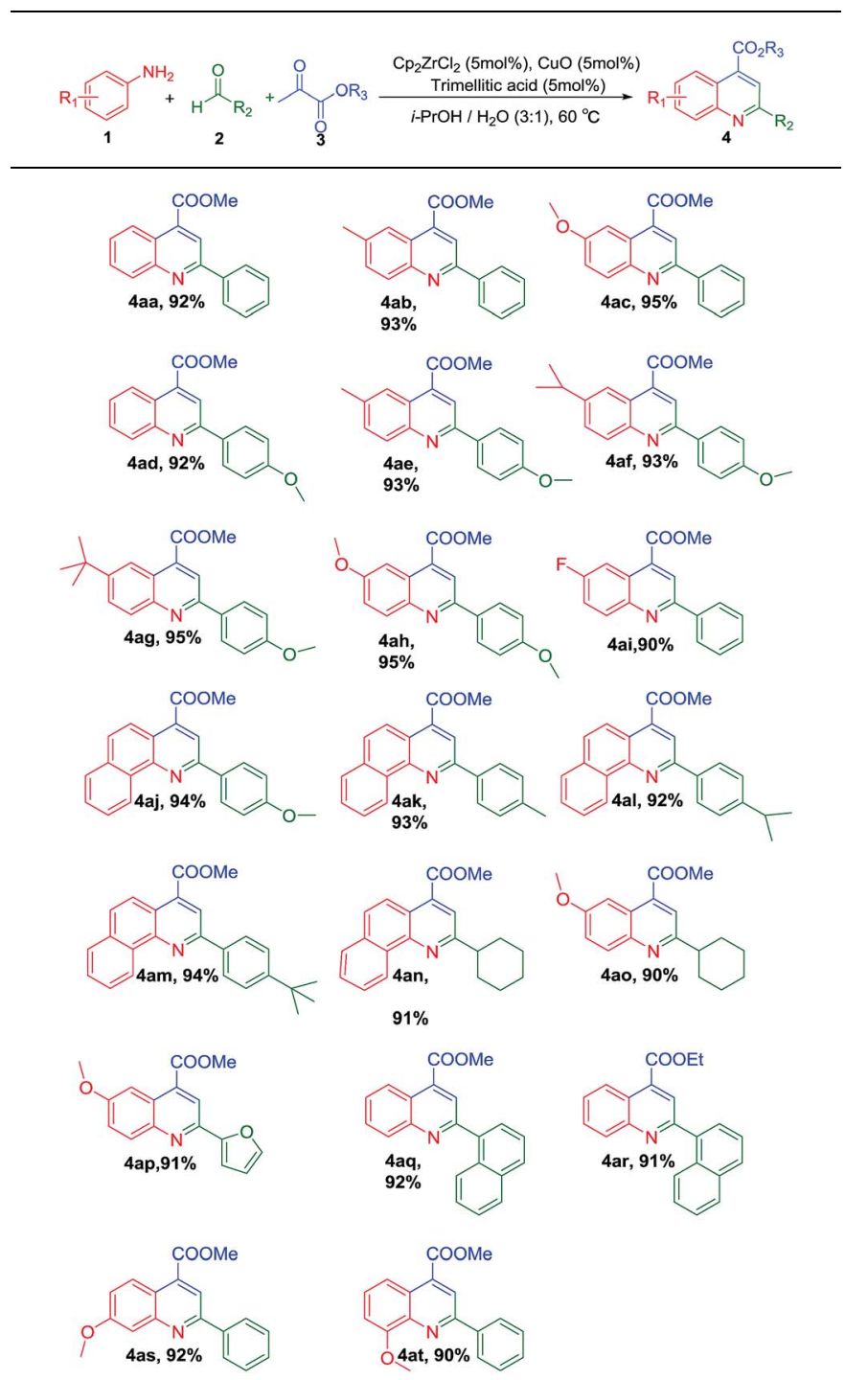

${ }^{a}$ All reactions were conducted using aldehyde $(1.0 \mathrm{mmol})$; arylamine (1.1 mmol); pyruvate (1.5 mmol); $\mathrm{Cp}_{2} \mathrm{ZrCl}_{2}(0.05 \mathrm{mmol}, 5 \mathrm{~mol} \%) ; \mathrm{CuO}$ (0.05 mmol, $5 \mathrm{~mol} \%)$; trimellitic acid $(0.05 \mathrm{mmol}, 5 \mathrm{~mol} \%) ; i$ $\mathrm{PrOH}: \mathrm{H}_{2} \mathrm{O}(3: 1,0.5 \mathrm{~mL})$; all reactions were carried out at $60{ }^{\circ} \mathrm{C}$ for 2 h. ${ }^{b}$ Isolated yield.

methyl or ethyl group. Aniline with methyl (4ab) and methoxyl (4ac) substituents led to the excellent results (90-91\%), when benzaldehyde and methyl pyruvate were used. The $p$-substituents of anilines were changed from methyl (4ae), $i$-propyl (4af), $t$-butyl (4ag) to methoxyl (4ah) reacted with 4-methoxybenzaldehyde and methyl pyruvate, the yields of the condensation reaction were $93-95 \%$. Under the similar condition, treating 4-fluroaniline and benzaldehyde with methyl pyruvate afforded the substituted quinoline (4ai) in $90 \%$ yield. Benzaldehydes with methoxyl (4aj), methyl (4ak), $i$-propyl (4al) or $t$ butyl (4am) substituents obtained $92-94 \%$ yields when they reacted with 1-naphthylamine and methyl pyruvate, which provided a convenient route for the construction of tricyclicquinolines. Aliphatic aldehydes such as cyclohexanecarbaldehyde was also readily introduced into this reaction, reacted with 1-naphthylamine or 4-methoxy aniline and methyl pyruvate afforded the desired products (4an, 4ao) in $91 \%$ and $90 \%$ yields, respectively. Heterocyclic furfuraldehyde afforded the desired product in $91 \%$ yield (4ap). 1-Naphthaldehyde reacted with aniline and methyl pyruvate or ethyl pyruvate under standard conditions afforded the multiply substituted quinolines in $92 \%$ and $91 \%$ yield (4aq and 4 ar). As expected, $m$-substituted aniline and aldehyde (4as) produced desired quinoline in $92 \%$ yield. Gratifyingly, the sterically hindered ortho-substituted anilines (4at) still furnished the desired product in more than $90 \%$ yield.

The zirconocene dichloride/trimellitic acid/CuO cooperative and relay catalytic system was successfully applied in the threecomponent coupling sequence reaction of aliphatic ketones and aromatic ketones under the optimized conditions (Table 3). The reaction results had not significantly effected by aliphatic ketones. The catalytic sequence reaction of 2-butanone with benzaldehyde and 1-naphthylamine afforded the products ( $\mathbf{4} \mathbf{b b})$ in $93 \%$ yields, whereas other chain ketones including 2-pentone, 2-hexanone and 2-heptanone afforded 2,4-substituted quinolines in $91-93 \%$ yield (4bd), (4be), (4bf). Cyclic ketones such as cyclohexanone (4bg) was also readily introduced into this reaction, the desired product being formed with yield of $96 \%$. Various halogens, such as fluorine, chlorine, bromine, iodine and electron-donating groups such as methyl were all tolerated in this reaction, afforded the products with 91-94\% yields ( $\mathbf{4} \mathbf{b h}, \mathbf{4 b \mathbf { b }}, \mathbf{4 b j}, \mathbf{4 b \mathbf { k }}$ and $\mathbf{4 b e}$ ). This triple cooperative and relay catalytic system were also applied in the three-component cascade reaction of aromatic ketone, such as anilines, benzaldehyde reacted with acetophenone afforded 2,4-diphenylquinoline in $\mathbf{9 0 \%}$ and $91 \%$ yield $(\mathbf{4 b l}$ and $\mathbf{4 b m})$, albeit with longer reaction time ( $12 \mathrm{~h})$. To our pleased, chain aldehyde can also be used as substrate for this reaction afforded 6-methoxy-4-ethyl-2propylquinoline in $90 \%$ yield with $12 \mathrm{~h}(\mathbf{4 b n})$. More importantly, this cooperative and relay catalytic system for synthesis of substituted quinoline could be easily scaled up and the desired disubstituted quinoline was obtained in $92 \%$ yield (Scheme 2).

To get more information about the reaction mechanism, several control experiments (Table 4) and parallel experiment (Scheme 3) were set up under the standard conditions. The three components cascade reaction of aniline, benzaldehyde and methyl pyruvate without catalyst or with $5 \mathrm{~mol} \% \mathrm{CuO}$ did not get the desired product at $60^{\circ} \mathrm{C}$ for $2 \mathrm{~h}$ (Table 4, entries 1 and 2). In the presence of $5 \mathrm{~mol} \%$ trimellitic acid, threecomponent sequence reaction afforded the desired quinoline in $14 \%$ yield (Table 4 , entry 3 ). With addition of $5 \mathrm{~mol} \% \mathrm{Cp}_{2^{-}}$ $\mathrm{ZrCl}_{2}$ in the reaction only obtained $17 \%$ yield of quinoline (Table 4, entry 4), which eliminated the possibility that $i$-propanol or water coordination with zirconocene dichloride released $\mathrm{HCl}$ promotes this reaction. With the assistance of $5 \mathrm{~mol} \%$ $\mathrm{Cp}_{2} \mathrm{ZrCl}_{2}$ and $5 \mathrm{~mol} \%$ trimellitic acid, the desired product was isolated in $44 \%$ yield (Table 4, entries 5). Adding $5 \mathrm{~mol} \% \mathrm{CuO}$ into this catalytic system, the yield of 4-methoxycarbonyl-2phenylquinoline was up to $92 \%$ (Table 4 , entry 6 ). It is clear 
Table 3 Zirconocene dichloride/trimellitic acid/copper oxide catalyzed three components tandem reaction of aldehydes, arylamines and ketones ${ }^{a, b}$

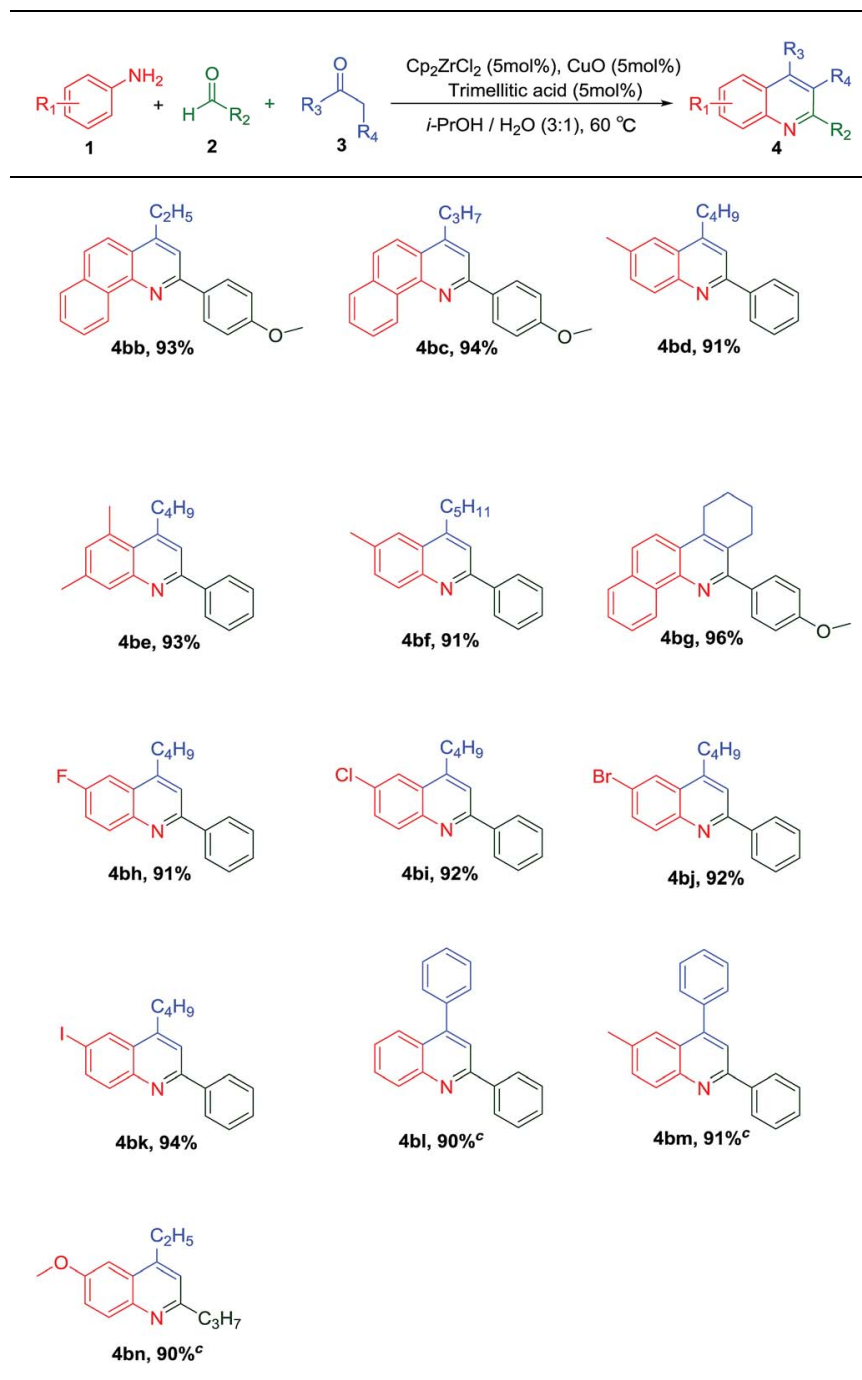

${ }^{a}$ Reaction conditions: a mixture of aldehyde $(1.0 \mathrm{mmol})$; arylamine $(1.1$ $\mathrm{mmol})$; ketone (1.5 mmol); $\mathrm{Cp}_{2} \mathrm{ZrCl}_{2}$ (0.05 mmol, $\left.5 \mathrm{~mol} \%\right)$; $\mathrm{CuO}$ (0.05 mmol, $5 \mathrm{~mol} \%)$; trimellitic acid (0.05 mmol, $5 \mathrm{~mol} \%) ; i$ PrOH : $\mathrm{H}_{2} \mathrm{O}(3: 1,0.5 \mathrm{~mL}), 60{ }^{\circ} \mathrm{C}$ for 8 h. ${ }^{b}$ Isolated yield. ${ }^{c} 12 \mathrm{~h}$.

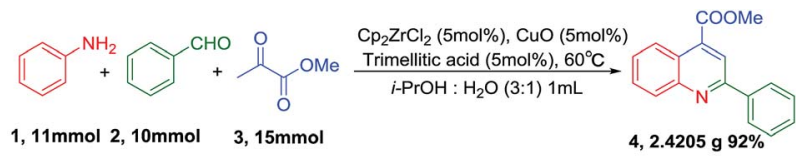

Scheme 2 Scaled up for the gram scale.

that the high efficiency of the coupling sequence reaction should not be attributed to zirconocene dichloride, trimellitic acid or $\mathrm{CuO}$ individually. We proposed that the cooperation of zirconocene dichloride, trimellitic acid and the relay of $\mathrm{CuO}$, resulted in the efficient cooperative and relay catalysis. The control experiments using $10 \mathrm{~mol} \% \mathrm{HCl}$ afforded the substituted quinolines in $10 \%$ yield, indicating $\mathrm{HCl}$ was not
Table 4 Control experiment ${ }^{a}$

\begin{tabular}{lllll}
\hline Entry & $\mathrm{CuO}(\mathrm{mol} \%)$ & $\begin{array}{l}\text { Trimellitic acid } \\
(\mathrm{mol} \%)\end{array}$ & $\begin{array}{l}\mathrm{Cp}_{2} \mathrm{ZrCl}_{2} \\
(\mathrm{~mol} \%)\end{array}$ & Yield $^{b}(\%)$ \\
\hline 1 & - & - & - & $\mathrm{ND}$ \\
2 & 5 & - & - & $\mathrm{ND}$ \\
3 & - & 5 & - & 14 \\
4 & - & - & 5 & 17 \\
5 & - & 5 & 5 & 44 \\
6 & 5 & 5 & 5 & 92
\end{tabular}

${ }^{a}$ Reaction conditions: a mixture of aldehyde $(1.0 \mathrm{mmol})$; aniline $(1.1$ mmol); methyl pyruvate (1.5 mmol); $i$-PrOH : $\mathrm{H}_{2} \mathrm{O}(3: 1,0.5 \mathrm{~mL})$; all reactions were carried out at $60{ }^{\circ} \mathrm{C}$ for $2 \mathrm{~h}$, ND $=$ no detected. ${ }^{b}$ Isolated yield.

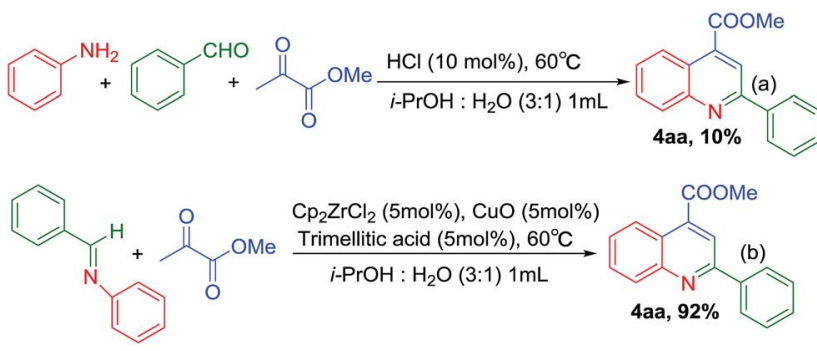

Scheme 3 The paralleled experiment.

catalytic species (Scheme 3a). This control experiments and parallel experiment indicated that zirconocene dichloride and trimellitic acid demonstrated good compatibility with $\mathrm{CuO}$ in three components cascade reaction, which presented a new cooperative and relay catalysis system for synthesis of multiply substituted quinolines from anilines, aldehydes and ketones. $N$ Arylimines and methyl pyruvate under the standard condition also afforded the desired product in $92 \%$ yield (Scheme $3 \mathrm{~b}$ ), which indicated that the imine was firstly formed in this reaction, followed by Mannich addition and cyclization.

The interaction of zirconocene dichloride and trimellitic acid in three-component coupling sequence reaction for synthesis of substituted quinolines were investigated by ${ }^{1} \mathrm{H}$ NMR and HRMS analyses. ${ }^{1} \mathrm{H}$ NMR experiments, which were conducted using $\mathrm{Cp}_{2} \mathrm{ZrCl}_{2}$ in $\mathrm{D}_{2} \mathrm{O}$ (Fig. 1), showed that no coordination occurred and only one $\mathrm{Cp}$ singlet of $\mathrm{Cp}_{2} \mathrm{ZrCl}_{2}$ at $\delta=6.49 \mathrm{ppm}(\bullet)$ was detected. When adding 1 equiv. trimellitic acid, a new zirconocene complex species II formed, which resonated at $\delta=6.57 \mathrm{ppm}\left({ }^{(}\right)$. Intensity of the Cp singlet at $\delta=$ 6.57 didn't increase as the time went on. Adding 2 equiv. aniline into this transformation, zirconocene dichloride (I) was consumed gradually in $\mathrm{D}_{2} \mathrm{O}$ and transformed to a new zirconocene species $\mathrm{Cp}_{2} \mathrm{Zr}(\mathrm{OOC})_{2} \mathrm{PhCOOH}$ (II). ${ }^{20}$ The above conclusion was also certified by HRMS analysis, corresponding to the $[\mathrm{II}+\mathrm{H}]^{+}$signal at $m / z 428.9921$ (Fig. S3-S6 $\dagger$ ). These observations clearly demonstrated that during the reaction, zirconocene dichloride readily converted into zirconocene complexes II, and presumably it was the organometallic binary acid catalyst. 


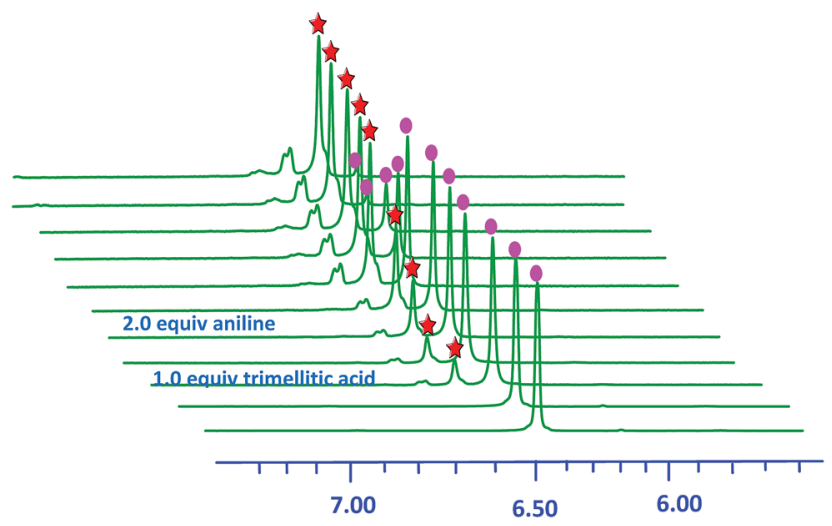

Fig. 1 Partial $400 \mathrm{MHz}^{1} \mathrm{H}$ NMR spectra $\left(\mathrm{D}_{2} \mathrm{O}\right)$ of a mixture of $\mathrm{Cp}_{2} \mathrm{ZrCl}_{2}$ (1.0 equiv.) and trimellitic acid (1.0 equiv.) with $\mathrm{PhNH}_{2}$ (2.0 equiv). $6.49 \mathrm{ppm}$ le $\left[\mathrm{Cp}_{2} \mathrm{ZrCl}_{2}\right] ; 6.57 \mathrm{ppm} \mathrm{I} \mathrm{Cp}_{2} \mathrm{Zr}(\mathrm{OOC})_{2} \mathrm{PhCOOH}$.

Taken ${ }^{1}$ HNMR, HRMS, control experiments and paralleled experiments together, a plausible catalytic cycle of zirconocene dichloride/trimellitic acid/CuO triple cooperative and relay catalytic system in three-component sequence reaction was illustrated in Scheme 4. Zirconocene dichloride I pre-catalyst activated by trimellitic acid and transformed to binary acid catalyst II in the presence of aniline. The incoming ketone coordinated to $\mathrm{Zr}$ center of II. In transition state A, enolation was accelerated as the carbonyl coordinated to oxytropic $\mathrm{Zr}$ and methyl formed hydrogen bond with the carboxyl oxygen of trimellitic acid. The carbon-carbon bond formation is illustrated in transition state A. The coordinated enolate then undergoes addition to the aldimine, which is activated by $\mathrm{H}^{+}$from the other carboxyl group of trimellitic acid. This transition state show cases the cooperative nature of this binary acid catalytic system. In transition state $\mathrm{B}$, the electron-rich benzene ring attacked the keto-carbonyl group to formed the intermediate dihydroquinoline. After the dihydroquinoline was released, the zirconocene catalyst II was regenerated from the transition state $\mathrm{B}$ by coordination of the carboxyl group again. The coordination of the dihydroquinoline and $\mathrm{CuO}$ may induce a combination of electron transfer and intramolecular rearrangement to give the desired product ${ }^{21}$ and $\mathrm{Cu}(0) \cdot \mathrm{H}_{2} \mathrm{O}$, which should be more stable

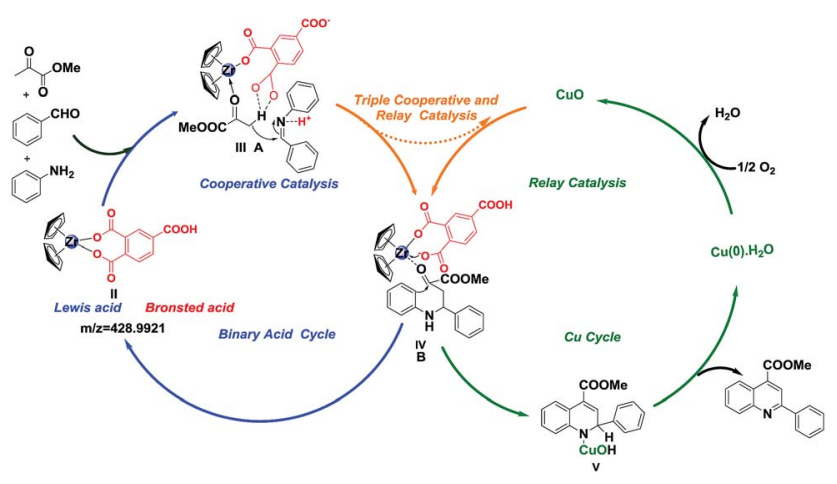

Scheme 4 Proposed mechanism of zirconocene dichloride/trimellitic $\mathrm{acid} / \mathrm{CuO}$ cooperative and relay catalysis for synthesis of substituted quinolines. than $\mathrm{Cu}(0)$ due to its coordination with $\mathrm{H}_{2} \mathrm{O}$. Active $\mathrm{Cu}(0) \cdot \mathrm{H}_{2} \mathrm{O}$ is facilely oxidized by oxygen in the air to restore $\mathrm{CuO}$, which enters next catalytic cycle.

\section{Conclusions}

In summary, we have developed a triple cooperative and relay catalysis system that the combination of organometallic Lewis acids and Brønsted acids with metal were developed for threecomponent cascade Mannich addition/C-C formative cyclization/oxidation reaction. The green syntheses of substituted quinolines were achieved from readily available anilines, aldehydes and aromatic or aliphatic ketones in good to excellent yields. ${ }^{1} \mathrm{H}$ NMR and HRMS analysis unveiled that $\mathrm{Cp}_{2} \mathrm{Zr}(\mathrm{OOC})_{2} \mathrm{PhCOOH}$ was catalytic specis, which significantly accelerated the condensation of aldehydes, anilines and ketones into dihydroquinolines with $i$-propanol and water as solvent. Meanwhile, $\mathrm{CuO}$ catalyzed oxydehydrogenation of dihydroquinolines to generate quinolines.

\section{Experimental}

\section{General methods and materials}

All manipulations were performed in an atmosphere of air. All reagents were purchased from the commercial approaches and used without further purification unless specified otherwise. ${ }^{1} \mathrm{H}$ and ${ }^{13} \mathrm{C}$ NMR spectra were recorded on a Bruker EQUINX55 (400 $\mathrm{MHz}$ for ${ }^{1} \mathrm{H}$; $101 \mathrm{MHz}$ for ${ }^{13} \mathrm{C}$ ) spectrometer in $\mathrm{CDCl}_{3}$. For ${ }^{1} \mathrm{H}$ NMR, tetramethylsilane (TMS) served as internal standard ( $\delta=$ 0 ) and ${ }^{1} \mathrm{H}$ NMR chemical shifts are reported in ppm downfield of tetramethylsilane and referenced to residual solvent peak $\left(\mathrm{CDCl}_{3}\right.$ at $\left.7.26 \mathrm{ppm}\right)$ unless otherwise noted. The data are reported as follows: chemical shift, integration, multiplicity ( $\mathrm{s}=$ singlet, $\mathrm{d}=$ doublet, $\mathrm{t}=$ triplet, $\mathrm{q}=$ quartet and $\mathrm{m}=$ multiplet), and coupling constant in $\mathrm{Hz}$. For ${ }^{13} \mathrm{C} \mathrm{NMR}, \mathrm{CDCl}_{3}$ was used as internal standard $(\delta=77.0)$ and spectra were obtained with complete proton decoupling. HRMS (ESI) analysis was performed and (HRMS) data were reported with sodium mass/ charge $(\mathrm{m} / \mathrm{z})$ ratios as values in atomic mass units. Column chromatography was performed on silica gel (230-400 mesh) and analytical thin layer chromatography was carried out using $250 \mu \mathrm{m}$ commercial silica gel plates. Visualization of the developed chromatogram was performed by UV absorbance and stained with an iodine vapor.

\section{Typical procedures for synthesis of substituted quinolones}

A $10 \mathrm{~mL}$ test tube equipped with a magnetic stirrer and a septum, was charged with aldehyde $(1.0 \mathrm{mmol})$, amine (1.1 $\mathrm{mmol})$, and the ketone $(1.5 \mathrm{mmol})$ in one portion. $\mathrm{Cp}_{2} \mathrm{ZrCl}_{2}$ (0.05 mmol, $5 \mathrm{~mol} \%$ ), CuO (0.05 mmol, $5 \mathrm{~mol} \%$ ) and trimellitic acid (0.05 mmol, 5 mol\%) were stirred in $i$-PrOH : $\mathrm{H}_{2} \mathrm{O}(3: 1) 0.5$ $\mathrm{mL}$. The reaction mixture was heated to $60{ }^{\circ} \mathrm{C}$ and stirred until the reaction was completed as indicated by TLC, then the reaction mixture was quenched with distilled water $(5.0 \mathrm{~mL})$. The aqueous phase was extracted with dichloride methane (3-5 $\mathrm{mL}$ ), dried over $\mathrm{Na}_{2} \mathrm{SO}_{4}$ and concentrated in vacuo to give the 
crude product. The crude product was purified by flash column chromatography on neutral silica gel (ethyl acetate:petroleum ether). Full experimental details and characterization data for all quinolines product are included in the ESI. $\dagger$

4-Methoxycarbonyl-2-phenylquinoline (4aa). Yield, 92\%; primrose yellow solid; $\mathrm{mp} 217-218^{\circ} \mathrm{C}$; Rf 0.51 (petroleum ether/ ethyl acetate $=10: 1)$; IR (KBr): 1728, 1593, 1346, 1250, 1203, 1149, 771, $694 \mathrm{~cm}^{-1} ;{ }^{1} \mathrm{H}$ NMR (400 MHz, $\left.\mathrm{CDCl}_{3}\right) \delta 8.75(\mathrm{~d}, J=$ $8.5 \mathrm{~Hz}, 1 \mathrm{H}), 8.41(\mathrm{~s}, 1 \mathrm{H}), 8.22(\mathrm{~s}, 3 \mathrm{H}), 7.77(\mathrm{~s}, 1 \mathrm{H}), 7.63(\mathrm{~s}, 1 \mathrm{H})$, 7.55 (s, 2H), 7.50 (d, $J=7.1 \mathrm{~Hz}, 1 \mathrm{H}), 4.07$ (s, 3H). ${ }^{13} \mathrm{C}$ NMR (101 $\left.\mathrm{MHz}, \mathrm{CDCl}_{3}\right) \delta 166.85,156.71,149.29,138.81,135.61,130.35$, 129.91, 129.74, 128.94, 127.81, 127.48, 125.43, 124.00, 120.34, 52.72. HRMS (ESI): $m / z$ called for $\mathrm{C}_{17} \mathrm{H}_{13} \mathrm{NO}_{2}[\mathrm{M}+\mathrm{H}]^{+}, 264.1019$; found, 264.1026.

6-Methyl-4-methoxycarbonyl-2-phenylquinoline (4ab). Yield, 93\%; primrose yellow solid; mp $212-213{ }^{\circ} \mathrm{C}$; Rf 0.45 (petroleum ether/ethyl acetate = $10: 1)$; IR (KBr): 1730, 1608, 1352, 1254, 1209, 1153, 775, $698 \mathrm{~cm}^{-1} ;{ }^{1} \mathrm{H}$ NMR (400 MHz, $\left.\mathrm{CDCl}_{3}\right) \delta 8.51(\mathrm{~s}$, $1 \mathrm{H}), 8.35(\mathrm{~s}, 1 \mathrm{H}), 8.19(\mathrm{~d}, J=7.3 \mathrm{~Hz}, 2 \mathrm{H}), 8.12(\mathrm{~d}, J=8.6 \mathrm{~Hz}, 1 \mathrm{H})$, 7.61-7.57 (m, 1H), $7.54(\mathrm{~s}, 2 \mathrm{H}), 7.47(\mathrm{~s}, 1 \mathrm{H}), 4.06(\mathrm{~s}, 3 \mathrm{H}), 2.58(\mathrm{~s}$, $3 \mathrm{H}) .{ }^{13} \mathrm{C} \mathrm{NMR}\left(101 \mathrm{MHz}, \mathrm{CDCl}_{3}\right) \delta 166.97,155.72,147.94$, 138.90, 138.01, 134.81, 132.18, 129.99, 129.53, 128.90, 127.36, 124.24, 124.02, 120.23, 52.65, 22.13. HRMS (ESI): $m / z$ called for $\mathrm{C}_{18} \mathrm{H}_{15} \mathrm{NO}_{2}[\mathrm{M}+\mathrm{H}]^{+}, 278.1176$; found, 278.1177.

6-Methoxy-4-methoxycarbonyl-2-phenylquinoline

(4ac). Yield, 95\%; primrose yellow solid; mp 215-219 ${ }^{\circ} \mathrm{C} ; \mathrm{Rf}$ 0.47 (petroleum ether/ethyl acetate $=10: 1$ ); IR (KBr): 1726, 1591, 1344, 1253, 1206, 1152, 774, $697 \mathrm{~cm}^{-1}$; ${ }^{1} \mathrm{H}$ NMR $(400 \mathrm{MHz}$, $\left.\mathrm{CDCl}_{3}\right) \delta 8.40(\mathrm{~s}, 1 \mathrm{H}), 8.21(\mathrm{~d}, J=2.7 \mathrm{~Hz}, 1 \mathrm{H}), 8.16(\mathrm{~d}, J=7.5 \mathrm{~Hz}$, $2 \mathrm{H}), 8.10(\mathrm{~d}, J=9.2 \mathrm{~Hz}, 1 \mathrm{H}), 7.52(\mathrm{~s}, 2 \mathrm{H}), 7.42(\mathrm{~d}, J=2.6 \mathrm{~Hz}, 2 \mathrm{H})$, $4.04(\mathrm{~s}, 3 \mathrm{H}), 3.97(\mathrm{~s}, 3 \mathrm{H}) .{ }^{13} \mathrm{C}$ NMR $\left(101 \mathrm{MHz} \mathrm{CDCl}_{3}\right) \delta 166.91$, 159.05, 154.03, 145.70, 138.92, 133.17, 131.72, 129.29, 128.88, 127.14, 125.55, 122.79, 120.69, 103.22, 55.57, 52.56. HRMS (ESI): $\mathrm{m} / z$ called for $\mathrm{C}_{17} \mathrm{H}_{13} \mathrm{NO}_{2}[\mathrm{M}+\mathrm{H}]^{+}, 294.1130$; found, 294.1125.

4-Methoxycarbonyl-2-[4-methoxyl]phenylquinoline (4ad). Yield, 92\%; primrose yellow solid; mp 220-221 ${ }^{\circ} \mathrm{C}$; Rf 0.49 (petroleum ether/ethyl acetate $=10: 1$ ); IR $(\mathrm{KBr}): 1731,1596$, 1349, 1253, 1206, 1152, 778, $698 \mathrm{~cm}^{-1} ;{ }^{1} \mathrm{H}$ NMR $(400 \mathrm{MHz}$, $\left.\mathrm{CDCl}_{3}\right) \delta 8.71(\mathrm{~d}, J=8.3 \mathrm{~Hz}, 1 \mathrm{H}), 8.36(\mathrm{~s}, 1 \mathrm{H}), 8.18(\mathrm{~d}, J=8.9 \mathrm{~Hz}$, $3 \mathrm{H}), 7.75(\mathrm{~d}, J=1.2 \mathrm{~Hz}, 1 \mathrm{H}), 7.59(\mathrm{~s}, 1 \mathrm{H}), 7.06(\mathrm{~d}, J=8.8 \mathrm{~Hz}, 2 \mathrm{H})$, 4.07 (s, 3H), 3.89 (s, 3H). ${ }^{13} \mathrm{C}$ NMR (101 MHz, $\left.\mathrm{CDCl}_{3}\right) \delta 166.96$, $161.15,156.27,149.28,135.50,131.38,130.10,129.83,128.85$, 127.39, 125.40, 123.67, 119.93, 114.33, 55.42, 52.70. HRMS (ESI): $m / z$ called for $\mathrm{C}_{18} \mathrm{H}_{15} \mathrm{NO}_{3}[\mathrm{M}+\mathrm{H}]^{+}$, 294.1125; found, 294.1130.

6-Methyl-4-methoxycarbonyl-2-[4-methoxyl]phenylquinoline (4ae). Yield, 93\%; yellow solid; mp 224-225 ${ }^{\circ} \mathrm{C}$; Rf 0.52 (petroleum ether/ethyl acetate $=10: 1)$; IR (KBr): 1729, 1596, 1348, 1254, 1207, 1151, 773, $696 \mathrm{~cm}^{-1} ;{ }^{1} \mathrm{H}$ NMR (400 MHz, $\mathrm{CDCl}_{3}$ ) $\delta 8.48(\mathrm{~s}, 1 \mathrm{H}), 8.32(\mathrm{~s}, 1 \mathrm{H}), 8.16(\mathrm{~d}, J=8.8 \mathrm{~Hz}, 2 \mathrm{H}), 8.08(\mathrm{~d}, J=$ $8.6 \mathrm{~Hz}, 1 \mathrm{H}), 7.59$ (dd, $J=8.6,1.6 \mathrm{~Hz}, 1 \mathrm{H}), 7.26$ (s, 2H), 7.05 (d, $J$ $=8.8 \mathrm{~Hz}, 2 \mathrm{H}), 4.07(\mathrm{~s}, 3 \mathrm{H}), 3.90(\mathrm{~s}, 3 \mathrm{H}), 2.58(\mathrm{~s}, 3 \mathrm{H}) .{ }^{13} \mathrm{C} \mathrm{NMR}$ $\left(101 \mathrm{MHz}, \mathrm{CDCl}_{3}\right) \delta 190.81,167.07,160.97,155.31,147.91$, 137.53, 134.73, 132.07, 131.98, 131.48, 129.76, 128.69, 124.22, 123.67, 119.81, 114.31, 114.28, 55.39, 52.62, 22.08. HRMS (ESI): $m / z$ called for $\mathrm{C}_{19} \mathrm{H}_{17} \mathrm{NO}_{3}[\mathrm{M}+\mathrm{H}]^{+}, 308.1281$; found, 308.1289.

6-i-Propyl-4-methoxycarbonyl-2-[4-methoxyl]phenylquinoline (4af). Yield, 93\%; yellow solid; mp 210-211 ${ }^{\circ} \mathrm{C}$; Rf 0.51 (petroleum ether/ethyl acetate $=10: 1$ ); IR (KBr): 1732, 1595, 1349, 1251, 1205, 1152, 774, $698 \mathrm{~cm}^{-1}$; ${ }^{1} \mathrm{H}$ NMR (400 MHz, $\left.\mathrm{CDCl}_{3}\right) \delta 8.54(\mathrm{~d}, J=1.4 \mathrm{~Hz}, 1 \mathrm{H}), 8.33(\mathrm{~s}, 1 \mathrm{H}), 8.15(\mathrm{~s}, 3 \mathrm{H}), 7.66$ $(\mathrm{d}, J=1.8 \mathrm{~Hz}, 1 \mathrm{H}), 7.05(\mathrm{~d}, J=8.8 \mathrm{~Hz}, 2 \mathrm{H}), 4.07(\mathrm{~s}, 3 \mathrm{H}), 3.89$ (s, $3 \mathrm{H}), 3.14$ (d, $J=13.6,6.8 \mathrm{~Hz}, 1 \mathrm{H}), 1.37$ (d, $J=6.9 \mathrm{~Hz}, 6 \mathrm{H}) .{ }^{13} \mathrm{C}$ NMR (101 MHz, $\left.\mathrm{CDCl}_{3}\right) \delta 167.11,160.97,155.45,148.29,148.21$, 134.92, 131.60, 130.00, 129.50, 128.72, 123.75, 121.70, 119.84, 114.29, 55.41, 52.60, 34.56, 23.88. HRMS (ESI): $\mathrm{m} / \mathrm{z}$ called for $\mathrm{C}_{21} \mathrm{H}_{21} \mathrm{NO}_{3}[\mathrm{M}+\mathrm{H}]^{+}$, 336.1594; found, 336.1589.

6-t-Butyl-4-methoxycarbonyl-2-[4-methoxyl]phenylquinoline (4ag). Yield, 95\%; yellow solid; mp $207-208{ }^{\circ} \mathrm{C}$; Rf 0.50 (petroleum ether/ethyl acetate $=10: 1)$; IR (KBr): 1733, 1596, 1349, 1252, 1205, 1143, 774, $698 \mathrm{~cm}^{-1} ;{ }^{1} \mathrm{H}$ NMR (400 MHz, $\mathrm{CDCl}_{3}$ ) $\delta 8.72(\mathrm{~d}, J=2.0 \mathrm{~Hz}, 1 \mathrm{H}), 8.34(\mathrm{~s}, 1 \mathrm{H}), 8.15(\mathrm{dd}, J=15.5,8.8 \mathrm{~Hz}$, $3 \mathrm{H}), 7.85$ (dd, $J=8.9,2.1 \mathrm{~Hz}, 1 \mathrm{H}), 7.05$ (d, $J=8.8 \mathrm{~Hz}, 2 \mathrm{H}), 4.08$ (s, 3H), 3.89 (s, 3H), 1.46 (s, 9H). ${ }^{13} \mathrm{C} \mathrm{NMR} \mathrm{(101} \mathrm{MHz,} \mathrm{CDCl}_{3}$ ) $\delta 167.12,160.97,155.62,150.36,147.90,135.08,131.62,129.59$, $128.73,123.44,120.40,119.88,114.29$, 55.41, 52.61, 35.29, 31.22. HRMS (ESI): $m / z$ called for $\mathrm{C}_{21} \mathrm{H}_{21} \mathrm{NO}_{3}[\mathrm{M}+\mathrm{H}]^{+}, 350.1751$; found, 350.1756 .

6-Methoxy-4-methoxycarbonyl-2-[4-methoxyl]phenylquinoline (4ah). Yield, 95\%; yellow solid; mp 210-211 ${ }^{\circ} \mathrm{C}$; Rf 0.48 (petroleum ether/ethyl acetate $=10: 1)$; IR (KBr): 1725, 1591, 1343, 1247, 1201, 1146, 767, $691 \mathrm{~cm}^{-1} ;{ }^{1} \mathrm{H}$ NMR (400 MHz, $\mathrm{CDCl}_{3}$ ) $\delta 8.38(\mathrm{~s}, 1 \mathrm{H}), 8.20(\mathrm{~d}, J=2.3 \mathrm{~Hz}, 1 \mathrm{H}), 8.14(\mathrm{~d}, J=8.6 \mathrm{~Hz}, 2 \mathrm{H}), 8.08$ $(\mathrm{d}, J=9.2 \mathrm{~Hz}, 1 \mathrm{H}), 7.41(\mathrm{~d}, J=9.2 \mathrm{~Hz}, 1 \mathrm{H}), 7.05(\mathrm{~d}, J=8.6 \mathrm{~Hz}$, 2H), 4.06 (s, 3H), 3.98 (s, 3H), 3.89 (s, 3H). ${ }^{13} \mathrm{C}$ NMR (101 MHz, $\left.\mathrm{CDCl}_{3}\right) \delta 167.06,160.79,158.78,153.78,145.70,133.23,131.59$, 131.52, 128.47, 125.15, 122.65, 120.32, 114.28, 103.32, 55.57, $55.40,52.55$. HRMS (ESI): $m / z$ called for $\mathrm{C}_{19} \mathrm{H}_{17} \mathrm{NO}_{4}[\mathrm{M}+\mathrm{H}]^{+}$, 324.1230; found, 324.1234.

6-Fluoro-4-methoxycarbonyl-2-[4-methoxyl]phenylquinoline (4ai). Yield, 90\%; yellow solid; mp 230-231 ${ }^{\circ} \mathrm{C}$; Rf 0.46 (petroleum ether/ethyl acetate $=10: 1)$; IR (KBr): 1723, 1585, 1342, 1245, 1200, 1144, 767, $691 \mathrm{~cm}^{-1} ;{ }^{1} \mathrm{H}$ NMR (400 MHz, $\mathrm{CDCl}_{3}$ ) $\delta 8.87(\mathrm{~d}, J=8.5 \mathrm{~Hz}, 1 \mathrm{H}), 8.57(\mathrm{~s}, 1 \mathrm{H}), 8.43(\mathrm{~s}, 3 \mathrm{H}), 7.92(\mathrm{~s}, 1 \mathrm{H})$, $7.89(\mathrm{~s}, 1 \mathrm{H}), 7.74(\mathrm{~s}, 2 \mathrm{H}), 7.70(\mathrm{~d}, J=7.1 \mathrm{~Hz}, 1 \mathrm{H}), 4.11(\mathrm{~s}, 3 \mathrm{H}) .{ }^{13} \mathrm{C}$ NMR (101 MHz, $\left.\mathrm{CDCl}_{3}\right) \delta 176.91,164.83,158.21,148.78,144.31$, $140.25,138.90,138.60,137.94,138.83,138.45,134.39,133.05$, 129.33, 51.65. HRMS (ESI): $m / z$ called for $\mathrm{C}_{17} \mathrm{H}_{12} \mathrm{FNO}_{2}[\mathrm{M}+\mathrm{H}]^{+}$, 282.1019; found, 282.1012.

4-Methoxycarbonyl-2-[4-methoxylphenyl]benzoquinoline (4aj). Yield, 94\%; yellow solid; mp 213-214 ${ }^{\circ} \mathrm{C}$; Rf 0.49 (petroleum ether/ethyl acetate $=10: 1)$; IR (KBr): 1733, 1597, 1351, 1255, 1209, 1154, 778, $697 \mathrm{~cm}^{-1} ;{ }^{1} \mathrm{H}$ NMR (400 MHz, $\mathrm{CDCl}_{3}$ ) $\delta 9.48(\mathrm{~d}, J=7.8 \mathrm{~Hz}, 1 \mathrm{H}), 8.59(\mathrm{~d}, J=9.2 \mathrm{~Hz}, 1 \mathrm{H}), 8.42(\mathrm{~s}, 1 \mathrm{H})$, $8.33(\mathrm{~d}, J=8.6 \mathrm{~Hz}, 2 \mathrm{H}), 7.90(\mathrm{~d}, J=7.5 \mathrm{~Hz}, 1 \mathrm{H}), 7.85(\mathrm{~d}, J=$ $9.2 \mathrm{~Hz}, 1 \mathrm{H}), 7.73$ (s, 2H), 7.09 (d, $J=8.6 \mathrm{~Hz}, 2 \mathrm{H}), 4.09$ (s, 3H), $3.91(\mathrm{~s}, 3 \mathrm{H}) .{ }^{13} \mathrm{C}$ NMR (101 MHz, $\left.\mathrm{CDCl}_{3}\right) \delta 167.19,161.03$, $154.45,147.28,135.39$, 133.48, 131.59, 131.52, 128.69, 128.52, 127.59, 126.97, 125.14, 122.37, 122.07, 119.02, 114.25, 55.40, 52.70. HRMS (ESI): $m / z$ called for $\mathrm{C}_{22} \mathrm{H}_{17} \mathrm{NO}_{3}[\mathrm{M}+\mathrm{H}]^{+}, 344.1281$; found, 344.1286 .

4-Methoxycarbonyl-2-[4-methylphenyl]benzoquinoline (4ak). Yield, 93\%; yellow solid; mp 225-226 ${ }^{\circ} \mathrm{C}$; Rf 0.53 (petroleum ether/ethyl acetate = $10: 1$ ); IR (KBr): 1736, 1598, 1352, 1254, 1208, 1155, 778, $697 \mathrm{~cm}^{-1} ;{ }^{1} \mathrm{H}$ NMR (400 MHz, $\left.\mathrm{CDCl}_{3}\right) \delta 9.50(\mathrm{~d}, J$ 
$=7.8 \mathrm{~Hz}, 1 \mathrm{H}), 8.60(\mathrm{~d}, J=9.2 \mathrm{~Hz}, 1 \mathrm{H}), 8.45(\mathrm{~s}, 1 \mathrm{H}), 8.27(\mathrm{~d}, J=$ $7.8 \mathrm{~Hz}, 2 \mathrm{H}), 7.86(\mathrm{~d}, J=9.2 \mathrm{~Hz}, 2 \mathrm{H}), 7.74(\mathrm{~s}, 2 \mathrm{H}), 7.38(\mathrm{~d}, J=$ $7.7 \mathrm{~Hz}, 2 \mathrm{H}), 4.09$ (s, 3H), 2.47 (s, 3H). ${ }^{13} \mathrm{C} \mathrm{NMR}\left(101 \mathrm{MHz}, \mathrm{CDCl}_{3}\right)$ $\delta 167.22,154.89,147.37,139.75,136.16,135.51,133.48,131.66$, $129.65,128.80,128.54,127.61,127.25,127.06,125.19,122.36$, 119.38, 52.73, 21.40. HRMS (ESI): $m / z$ called for $\mathrm{C}_{22} \mathrm{H}_{17} \mathrm{NO}_{3}[\mathrm{M}+$ $\mathrm{H}]^{+}, 328.1332$; found, 328.1342.

4-Methoxycarbonyl-2-[4-i-propylphenyl]benzoquinoline (4al). Yield, 92\%; yellow solid; mp 229-230 ${ }^{\circ} \mathrm{C}$; Rf 0.52 (petroleum ether/ ethyl acetate = $10: 1)$; IR (KBr): 1721, 1583, 1340, 1244, 1197, 1141, $762,683 \mathrm{~cm}^{-1} ;{ }^{1} \mathrm{H}$ NMR $\left(400 \mathrm{MHz}, \mathrm{CDCl}_{3}\right) \delta 9.50(\mathrm{~d}, J=8.0 \mathrm{~Hz}$, $1 \mathrm{H}), 8.61(\mathrm{~d}, J=9.2 \mathrm{~Hz}, 1 \mathrm{H}), 8.46(\mathrm{~s}, 1 \mathrm{H}), 8.30(\mathrm{~d}, J=8.2 \mathrm{~Hz}, 2 \mathrm{H})$, 7.91-7.83 (m, 2H), 7.77-7.68 (m, 2H), $7.45(\mathrm{~d}, J=8.2 \mathrm{~Hz}, 2 \mathrm{H}), 4.08$ $(\mathrm{s}, 3 \mathrm{H}), 3.04(\mathrm{dt}, J=13.8,6.9 \mathrm{~Hz}, 1 \mathrm{H}), 1.36(\mathrm{~d}, J=7.0 \mathrm{~Hz}, 6 \mathrm{H}) .{ }^{13} \mathrm{C}$ NMR (101 MHz, $\mathrm{CDCl}_{3}$ ) $\delta$ 167.20, 154.99, 150.66, 147.39, 136.64, 135.47, 133.48, 131.68, 128.80, 128.53, 127.60, 127.43, 127.04, 125.22, 122.39, 122.37, 119.50, 52.71, 34.07, 23.97. HRMS (ESI): $m / z$ called for $\mathrm{C}_{24} \mathrm{H}_{21} \mathrm{NO}_{3}[\mathrm{M}+\mathrm{H}]^{+}, 356.1645$; found, 356.1650.

4-Methoxycarbonyl-2-[4-t-butylphenyl]benzoquinoline (4am). Yield, 94\%; primrose yellow solid; mp 215-216 ${ }^{\circ} \mathrm{C}$; Rf 0.48 (petroleum ether/ethyl acetate $=10: 1$ ); IR (KBr): 1721, 1585, 1342, 1245, 1294, 1140, 765, $685 \mathrm{~cm}^{-1} ;{ }^{1} \mathrm{H}$ NMR (400 MHz, $\left.\mathrm{CDCl}_{3}\right) \delta 9.51$ $(\mathrm{d}, J=7.9 \mathrm{~Hz}, 1 \mathrm{H}), 8.61(\mathrm{~d}, J=9.2 \mathrm{~Hz}, 1 \mathrm{H}), 8.47(\mathrm{~s}, 1 \mathrm{H}), 8.30(\mathrm{~d}, J=$ $8.4 \mathrm{~Hz}, 2 \mathrm{H}), 7.88(\mathrm{~s}, 2 \mathrm{H}), 7.78-7.71(\mathrm{~m}, 2 \mathrm{H}), 7.62(\mathrm{~d}, J=8.4 \mathrm{~Hz}, 2 \mathrm{H})$, $4.09(\mathrm{~s}, 3 \mathrm{H}), 1.43(\mathrm{~s}, 9 \mathrm{H}) .{ }^{13} \mathrm{C} \mathrm{NMR}\left(101 \mathrm{MHz}, \mathrm{CDCl}_{3}\right) \delta$ 167.22, $154.97,152.90,147.42,136.24,135.51,133.49$, 131.69, 128.82, $128.54,127.60,127.16,125.90,125.22,122.40,122.37,119.54$, $52.73,34.82,31.33$. HRMS (ESI): $m / z$ called for $\mathrm{C}_{25} \mathrm{H}_{23} \mathrm{NO}_{3}[\mathrm{M}+\mathrm{H}]^{+}$, 370.1802; found, 370.1805 .

4-Methoxycarbonyl-2-cyclohexylbenzoquinoline (4an). Yield, 91\%; primrose yellow solid; $\mathrm{mp} 213-214{ }^{\circ} \mathrm{C}$; Rf 0.47 (petroleum ether/ethyl acetate $=10: 1)$; IR (KBr): 1729, 1595, 1345, 1253, 1204, 1151, 774, $698 \mathrm{~cm}^{-1} ;{ }^{1} \mathrm{H}$ NMR $\left(400 \mathrm{MHz}, \mathrm{CDCl}_{3}\right) \delta 9.42(\mathrm{~d}, J$ $=7.7 \mathrm{~Hz}, 1 \mathrm{H}), 8.57(\mathrm{~d}, J=9.2 \mathrm{~Hz}, 1 \mathrm{H}), 7.89(\mathrm{~s}, 2 \mathrm{H}), 7.85(\mathrm{~d}, J=$ $9.3 \mathrm{~Hz}, 1 \mathrm{H}), 7.71$ (d, $J=1.7 \mathrm{~Hz}, 2 \mathrm{H}), 4.06(\mathrm{~s}, 3 \mathrm{H}), 3.04(\mathrm{~s}, 1 \mathrm{H})$, $2.14(\mathrm{~d}, J=11.9 \mathrm{~Hz}, 2 \mathrm{H}), 1.96(\mathrm{~d}, J=12.9 \mathrm{~Hz}, 2 \mathrm{H}), 1.80(\mathrm{~d}, J=$ $11.7 \mathrm{~Hz}, 2 \mathrm{H}), 1.53$ (d, $J=12.8 \mathrm{~Hz}, 4 \mathrm{H}) .{ }^{13} \mathrm{C}$ NMR $(101 \mathrm{MHz}$, $\left.\mathrm{CDCl}_{3}\right) \delta 167.41,164.84,135.05,133.30,131.54,128.28,127.48$, 126.90, 125.07, 122.40, 120.96, 52.60, 46.99, 32.91, 26.58, 26.18. HRMS (ESI): $m / z$ called for $\mathrm{C}_{21} \mathrm{H}_{21} \mathrm{NO}_{3}[\mathrm{M}+\mathrm{H}]^{+}, 320.1645$; found, 320.1648 .

6-Methoxy-4-methoxycarbonyl-2-cyclohexylquinoline (4ao). Yield, 90\%; primrose yellow solid; mp 203-204 ${ }^{\circ} \mathrm{C}$; Rf 0.50 (petroleum ether/ethyl acetate $=10: 1$ ); IR $(\mathrm{KBr})$ : 1733, 1598, 1349, 1253, 1206, 1152, 775, $697 \mathrm{~cm}^{-1} ;{ }^{1} \mathrm{H}$ NMR $(400 \mathrm{MHz}$, $\left.\mathrm{CDCl}_{3}\right) \delta 8.17(\mathrm{~d}, J=2.7 \mathrm{~Hz}, 1 \mathrm{H}), 7.99(\mathrm{~d}, J=9.2 \mathrm{~Hz}, 1 \mathrm{H}), 7.85(\mathrm{~s}$, $1 \mathrm{H}), 7.37$ (dd, $J=9.2,2.8 \mathrm{~Hz}, 1 \mathrm{H}), 4.03(\mathrm{~s}, 3 \mathrm{H}), 3.96(\mathrm{~s}, 3 \mathrm{H}), 2.01$ (s, 1H), 1.77-1.59 (m, 4H), 1.33-1.24 (m, 4H), 1.01-0.89 (m, 2H). ${ }^{13} \mathrm{C}$ NMR $\left(101 \mathrm{MHz}, \mathrm{CDCl}_{3}\right) \delta 167.13,163.49,158.51,145.18$, 133.01, 130.96, 130.88, 125.14, 122.22, 121.43, 103.32, 55.53, 52.43, 47.08, 32.81, 26.51, 26.04. HRMS (ESI): $\mathrm{m} / \mathrm{z}$ called for $\mathrm{C}_{18} \mathrm{H}_{21} \mathrm{NO}_{3}[\mathrm{M}+\mathrm{Na}]^{+}$, 322.1414; found, 322.1421.

6-Methoxy-4-methoxycarbonyl-2-furylquinoline (4ap). Yield, 91\%; claybank; mp 210-211 ${ }^{\circ} \mathrm{C}$; Rf 0.51 (petroleum ether/ethyl acetate $=10: 1$ ); IR (KBr): 1720, 1583, 1340, 1243, 1194, 1142, 764, $683 \mathrm{~cm}^{-1} ;{ }^{1} \mathrm{H}$ NMR $\left(400 \mathrm{MHz}, \mathrm{CDCl}_{3}\right) \delta 8.35$ (s, 1H), 8.20 (d,
$J=2.6 \mathrm{~Hz}, 1 \mathrm{H}), 8.06(\mathrm{~d}, J=9.3 \mathrm{~Hz}, 1 \mathrm{H}), 7.62(\mathrm{~s}, 1 \mathrm{H}), 7.40(\mathrm{dd}, J=$ 9.2, $2.6 \mathrm{~Hz}, 1 \mathrm{H}), 7.19(\mathrm{~d}, J=3.3 \mathrm{~Hz}, 1 \mathrm{H}), 6.98(\mathrm{~s}, 1 \mathrm{H}), 4.05(\mathrm{~s}, 3 \mathrm{H})$, $3.97(\mathrm{~s}, 3 \mathrm{H}) .{ }^{13} \mathrm{C} \mathrm{NMR}\left(101 \mathrm{MHz}, \mathrm{CDCl}_{3}\right) \delta 169.16,168.26$, $166.72,159.03,153.30,146.21,145.46,143.92,133.20,131.35$, 125.50, 122.95, 119.44, 112.27, 109.55, 103.47, 55.59, 52.60. HRMS (ESI): $m / z$ called for $\mathrm{C}_{16} \mathrm{H}_{13} \mathrm{NO}_{4}[\mathrm{M}+\mathrm{H}]^{+}, 284.0917$; found, 284.0922.

4-Methoxycarbonyl-2-naphthylquinoline (4aq). Yield, 92\%; primrose yellow solid; $\mathrm{mp} 233-234^{\circ} \mathrm{C}$; Rf 0.47 (petroleum ether/ ethyl acetate $=10: 1)$; IR (KBr): 1717, 1585, 1340, 1242, 1195, 1141, 763, $685 \mathrm{~cm}^{-1} ;{ }^{1} \mathrm{H}$ NMR $\left(400 \mathrm{MHz}, \mathrm{CDCl}_{3}\right) \delta 8.88(\mathrm{~d}, J=$ $8.5 \mathrm{~Hz}, 1 \mathrm{H}), 8.32(\mathrm{~d}, J=8.4 \mathrm{~Hz}, 1 \mathrm{H}), 8.27(\mathrm{~s}, 1 \mathrm{H}), 8.16(\mathrm{~d}, J=$ $8.1 \mathrm{~Hz}, 1 \mathrm{H}), 8.02-7.96(\mathrm{~m}, 2 \mathrm{H}), 7.85(\mathrm{t}, J=7.6 \mathrm{~Hz}, 1 \mathrm{H}), 7.79-7.71$ $(\mathrm{m}, 2 \mathrm{H}), 7.64(\mathrm{t}, J=7.7 \mathrm{~Hz}, 1 \mathrm{H}), 7.54(\mathrm{dt}, J=13.4,6.6 \mathrm{~Hz}, 2 \mathrm{H})$, 4.07 (s, 3H). ${ }^{13} \mathrm{C}$ NMR (101 MHz, $\left.\mathrm{CDCl}_{3}\right) \delta 166.73,158.97$, $149.15,137.87,135.19,134.05,131.14,130.33,130.07,129.55$, 128.52, 127.99, 126.87, 126.13, 125.53, 124.50, 123.87, 52.76. HRMS (ESI): $m / z$ called for $\mathrm{C}_{21} \mathrm{H}_{15} \mathrm{NO}_{3}[\mathrm{M}+\mathrm{H}]^{+}, 314.1176$; found, 314.1180.

4-Ethoxycarbonyl-2-naphthylquinoline (4ar). Yield, 91\%; yellow solid; mp 235-236 ${ }^{\circ} \mathrm{C}$; Rf 0.46 (petroleum ether/ethyl acetate = $10: 1)$; IR (KBr): 1726, 1589, 1343, 1247, 1201, 1145, $763,688 \mathrm{~cm}^{-1}$; ${ }^{1} \mathrm{H}$ NMR $\left(400 \mathrm{MHz}, \mathrm{CDCl}_{3}\right) \delta 8.85(\mathrm{~d}, J=8.6 \mathrm{~Hz}$, $1 \mathrm{H}), 8.29(\mathrm{~d}, J=8.3 \mathrm{~Hz}, 1 \mathrm{H}), 8.23(\mathrm{~s}, 1 \mathrm{H}), 8.13(\mathrm{~d}, J=8.2 \mathrm{~Hz}, 1 \mathrm{H})$, 8.01-7.94 (m, 2H), $7.83(\mathrm{~s}, 1 \mathrm{H}), 7.75(\mathrm{~d}, J=0.9 \mathrm{~Hz}, 2 \mathrm{H}), 7.65-7.60$ $(\mathrm{m}, 1 \mathrm{H}), 7.53(\mathrm{~d}, J=1.8 \mathrm{~Hz}, 2 \mathrm{H}), 4.54(\mathrm{~s}, 2 \mathrm{H}), 1.46(\mathrm{~s}, 3 \mathrm{H}) .{ }^{13} \mathrm{C}$ NMR $\left(101 \mathrm{MHz}, \mathrm{CDCl}_{3}\right) \delta 166.34,158.98,149.12,137.94,135.69$, $134.04,131.17,130.32$, 130.02, 129.51, 128.50, 127.94, 126.85, 126.13, 125.39, 124.30, 123.90, 61.93, 14.31. HRMS (ESI): $\mathrm{m} / \mathrm{z}$ called for $\mathrm{C}_{21} \mathrm{H}_{21} \mathrm{NO}_{3}[\mathrm{M}+\mathrm{H}]^{+}, 328.1332$; found, 328.1335 .

7-Methoxy-4-methoxycarbonyl-2-phenylquinoline (4as). Yield, 92\%; primrose yellow solid; mp 215-216 ${ }^{\circ} \mathrm{C}$; Rf 0.52 (petroleum ether/ethyl acetate = $10: 1$ ); IR (KBr): 1726, 1589, 1345, 1248, 1186, 1146, 769, $682 \mathrm{~cm}^{-1} ;{ }^{1} \mathrm{H}$ NMR $(400 \mathrm{MHz}$, $\left.\mathrm{CDCl}_{3}\right) \delta 8.67(\mathrm{~d}, J=9.3 \mathrm{~Hz}, 1 \mathrm{H}), 8.27(\mathrm{~s}, 1 \mathrm{H}), 8.21-8.17(\mathrm{~m}, 2 \mathrm{H})$, $7.55(\mathrm{~s}, 3 \mathrm{H}), 7.52-7.47(\mathrm{~m}, 1 \mathrm{H}), 7.30(\mathrm{~d}, J=2.7 \mathrm{~Hz}, 1 \mathrm{H}), 4.07(\mathrm{~s}$, $3 \mathrm{H}), 4.00(\mathrm{~s}, 3 \mathrm{H}) .{ }^{13} \mathrm{C}$ NMR $\left(101 \mathrm{MHz}, \mathrm{CDCl}_{3}\right) \delta 166.95,160.85$, 157.16, 151.27, 139.01, 135.33, 129.61, 128.90, 127.44, 126.52, 120.95, 119.26, 118.10, 108.10, 55.55, 52.67. HRMS (ESI): $\mathrm{m} / \mathrm{z}$ called for $\mathrm{C}_{18} \mathrm{H}_{15} \mathrm{NO}_{3}[\mathrm{M}+\mathrm{H}]^{+}$, 294.1125; found, 294.1133.

8-Methoxy-4-methoxycarbonyl-2-phenylquinoline (4at). Yield, 90\%; primrose yellow solid; mp 217-218 ${ }^{\circ} \mathrm{C}$; Rf 0.49 (petroleum ether/ethyl acetate = $10: 1$ ); IR (KBr): 1724, 1588, 1342, 1247, 1187, 1141, 765, $684 \mathrm{~cm}^{-1}$; ${ }^{1} \mathrm{H}$ NMR $(400 \mathrm{MHz}$, $\left.\mathrm{CDCl}_{3}\right) \delta 8.37(\mathrm{~s}, 1 \mathrm{H}), 8.25(\mathrm{~d}, J=8.5 \mathrm{~Hz}, 1 \mathrm{H}), 8.20(\mathrm{~d}, J=8.3 \mathrm{~Hz}$, $2 \mathrm{H}), 7.51(\mathrm{~s}, 1 \mathrm{H}), 7.10(\mathrm{~d}, J=7.6 \mathrm{~Hz}, 1 \mathrm{H}), 7.04(\mathrm{~d}, J=8.3 \mathrm{~Hz}, 2 \mathrm{H})$, $4.11(\mathrm{~s}, 3 \mathrm{H}), 4.06(\mathrm{~s}, 3 \mathrm{H}), 3.89(\mathrm{~s}, 3 \mathrm{H}) .{ }^{13} \mathrm{C} \mathrm{NMR}\left(101 \mathrm{MHz}, \mathrm{CDCl}_{3}\right)$ $\delta$ 167.08, 161.07, 155.59, 155.10, 141.29, 135.71, 131.58, 128.94, 127.54, 124.77, 120.21, 117.13, 114.27, 108.38, 56.25, 55.39, 52.69. HRMS (ESI): $m / z$ called for $\mathrm{C}_{19} \mathrm{H}_{17} \mathrm{NO}_{4}[\mathrm{M}+\mathrm{H}]^{+}, 323.1154$; found, 323.1158 .

4-Ethoxyl-2-[4-methylphenyl]benzoquinoline (4bb). Yield, 93\%; primrose yellow solid; $\mathrm{mp} 221-225{ }^{\circ} \mathrm{C}$; Rf 0.43 (petroleum ether/ethyl acetate $=10: 1)$; IR (KBr): 3078, 2962, 2931, 1611, 1510, $1459 \mathrm{~cm}^{-1} ;{ }^{1} \mathrm{H}$ NMR $\left(400 \mathrm{MHz}, \mathrm{CDCl}_{3}\right) \delta 9.52(\mathrm{~d}, J=$ $8.0 \mathrm{~Hz}, 1 \mathrm{H}), 8.32(\mathrm{~d}, J=8.8 \mathrm{~Hz}, 2 \mathrm{H}), 7.91(\mathrm{~d}, J=4.9 \mathrm{~Hz}, 2 \mathrm{H}), 7.81$ $(\mathrm{d}, J=7.4 \mathrm{~Hz}, 4 \mathrm{H}), 7.09(\mathrm{~d}, J=8.8 \mathrm{~Hz}, 2 \mathrm{H}), 3.91(\mathrm{~s}, 3 \mathrm{H}), 3.18(\mathrm{~s}$, 
2H), $1.46(\mathrm{~s}, 3 \mathrm{H}) .{ }^{13} \mathrm{C}$ NMR (101 MHz, $\left.\mathrm{CDCl}_{3}\right) \delta 160.67,154.90$, 150.16, 146.21, 133.54, 132.75, 132.34, 128.72, 127.84, 127.53, 126.65, 125.17, 123.52, 120.95, 117.52, 114.16, 55.41, 25.84, 14.64. HRMS (ESI): $m / z$ called for $\mathrm{C}_{21} \mathrm{H}_{21} \mathrm{NO}_{3}[\mathrm{M}+\mathrm{H}]^{+}, 336.1594$; found, 336.1589. HRMS (ESI): $m / z$ called for $\mathrm{C}_{22} \mathrm{H}_{19} \mathrm{NO}[\mathrm{M}+\mathrm{H}]^{+}$, 314.1539; found, 314.1542.

4-Propyl-2-[4-methylphenyl]benzoquinoline (4bc). Yield, 94\%; white solid; mp 229-221 ${ }^{\circ} \mathrm{C}$; Rf 0.45 (petroleum ether/ethyl acetate $=10: 1)$; IR (KBr): 3076, 2957, 2929, 1597, 1498, 1456 $\mathrm{cm}^{-1} ;{ }^{1} \mathrm{H}$ NMR $\left(400 \mathrm{MHz}, \mathrm{CDCl}_{3}\right) \delta 9.55(\mathrm{~d}, J=8.1 \mathrm{~Hz}, 1 \mathrm{H}), 8.33$ $(\mathrm{d}, J=8.8 \mathrm{~Hz}, 2 \mathrm{H}), 7.90(\mathrm{~s}, 2 \mathrm{H}), 7.79(\mathrm{~s}, 4 \mathrm{H}), 7.10(\mathrm{~d}, J=8.8 \mathrm{~Hz}$, 2H), 3.91 (s, 3H), 3.11 (s, 2H), 1.87 (d, $J=7.6 \mathrm{~Hz}, 2 \mathrm{H}), 1.09$ (s, $3 \mathrm{H}) .{ }^{13} \mathrm{C}$ NMR $\left(101 \mathrm{MHz}, \mathrm{CDCl}_{3}\right) \delta 160.68,154.66,148.71$, $133.55,132.72,132.35,128.73,127.86,127.55,126.66,125.18$, 123.74, 121.16, 118.48, 114.16, 55.41, 34.90, 23.71, 14.20. HRMS (ESI): $m / z$ called for $\mathrm{C}_{23} \mathrm{H}_{21} \mathrm{NO}[\mathrm{M}+\mathrm{H}]^{+}, 328.1696$; found, 328.1702 .

6-Methyl-4-butyl-2-phenylquinoline (4bd). Yield, 91\%; white solid; mp 222-223 ${ }^{\circ} \mathrm{C}$; Rf 0.47 (petroleum ether/ethyl acetate $=$ 10 : 1); IR (KBr): 3071, 2954, 2923, 1596, 1491, $1451 \mathrm{~cm}^{-1} ;{ }^{1} \mathrm{H}$ NMR (400 MHz, $\left.\mathrm{CDCl}_{3}\right) \delta 7.94(\mathrm{~s}, 2 \mathrm{H}), 7.46(\mathrm{~s}, 2 \mathrm{H}), 7.14(\mathrm{~d}, J=$ $34.7 \mathrm{~Hz}, 4 \mathrm{H}), 5.92(\mathrm{~s}, 1 \mathrm{H}), 2.38$ (s, 5H), 1.55 (s, 2H), $1.33(\mathrm{~s}, 2 \mathrm{H})$, 0.87 (s, 3H). ${ }^{13} \mathrm{C}$ NMR (101 MHz, $\left.\mathrm{CDCl}_{3}\right) \delta 188.57,167.29$, 140.31, 135.88, 135.77, 130.67, 129.71, 128.19, 126.99, 125.33, 92.55, 31.95, 30.40, 22.36, 20.94, 13.67. HRMS (ESI): $\mathrm{m} / \mathrm{z}$ called for $\mathrm{C}_{20} \mathrm{H}_{21} \mathrm{~N}[\mathrm{M}+\mathrm{H}]^{+}, 276.1713$; found, 276.1716.

5,7-Dimethyl-4-butyl-2-phenylquinoline (4be). Yield, 93\%; white solid; mp 219-220 ${ }^{\circ} \mathrm{C}$; Rf 0.46 (petroleum ether/ethyl acetate = $10: 1$ ); IR (KBr): 3078, 2961, 2929, 1563, 1498, 1457 $\mathrm{cm}^{-1} ;{ }^{1} \mathrm{H}$ NMR (400 MHz, $\left.\mathrm{CDCl}_{3}\right) \delta 7.99(\mathrm{~s}, 2 \mathrm{H}), 7.47(\mathrm{~d}, J=$ $6.1 \mathrm{~Hz}, 2 \mathrm{H}), 6.91(\mathrm{~s}, 1 \mathrm{H}), 6.85(\mathrm{~s}, 2 \mathrm{H}), 5.95(\mathrm{~s}, 1 \mathrm{H}), 2.47(\mathrm{~s}, 2 \mathrm{H})$, $2.36(\mathrm{~s}, 6 \mathrm{H}), 1.60(\mathrm{~s}, 2 \mathrm{H}), 1.38(\mathrm{~s}, 2 \mathrm{H}), 0.91(\mathrm{~s}, 3 \mathrm{H}) .{ }^{13} \mathrm{C}$ NMR $(101$ $\left.\mathrm{MHz}, \mathrm{CDCl}_{3}\right) \delta 188.50,167.03,140.37,138.81,138.31,130.69$, 128.21, 127.64, 127.03, 122.89, 92.70, 31.97, 30.47, 22.38, 21.24, 13.69. HRMS (ESI): $m / z$ called for $\mathrm{C}_{21} \mathrm{H}_{23} \mathrm{~N}[\mathrm{M}+\mathrm{H}]^{+}, 290.1817$; found, 290.1819 .

6-Methyl-4-pentyl-2-phenylquinoline (4bf). Yield, 91\%; white solid; mp 215-216 ${ }^{\circ} \mathrm{C}$; Rf 0.47 (petroleum ether/ethyl acetate $=$ 10 : 1); IR (KBr): 3075, 2959, 2928, 1599, 1495, $1453 \mathrm{~cm}^{-1} ;{ }^{1} \mathrm{H}$ NMR (400 MHz, $\left.\mathrm{CDCl}_{3}\right) \delta 7.95(\mathrm{~d}, J=6.5 \mathrm{~Hz}, 2 \mathrm{H}), 7.47(\mathrm{~s}, 2 \mathrm{H})$, $7.20(\mathrm{~d}, J=7.8 \mathrm{~Hz}, 2 \mathrm{H}), 7.09(\mathrm{~d}, J=7.8 \mathrm{~Hz}, 2 \mathrm{H}), 5.92(\mathrm{~s}, 1 \mathrm{H}), 2.39$ (s, 5H), 1.56 (s, 2H), $1.28(\mathrm{~s}, 4 \mathrm{H}), 0.86(\mathrm{~s}, 3 \mathrm{H}) .{ }^{13} \mathrm{C}$ NMR (101 $\left.\mathrm{MHz}, \mathrm{CDCl}_{3}\right) \delta 188.57,167.32,140.32,135.89,135.78,130.67$, 129.72, 128.19, 126.99, 125.33, 92.54, 32.21, 31.39, 27.93, 22.19, 20.94, 13.81. HRMS (ESI): $m / z$ called for $\mathrm{C}_{21} \mathrm{H}_{23} \mathrm{~N}[\mathrm{M}+\mathrm{H}]^{+}$, 290.1817; found, 290.1819.

6-(4-Methoxyphenyl)-7,8,9,10-tetrahydrobenzophenanthridine (4bg). Yield, 96\%; white solid; mp $182-183^{\circ} \mathrm{C}$; Rf 0.48 (petroleum ether/ethyl acetate $=10: 1)$; IR (KBr): 3078, 2962, 2931, 1591, 1484, $1447 \mathrm{~cm}^{-1} ;{ }^{1} \mathrm{H}$ NMR $\left(400 \mathrm{MHz}, \mathrm{CDCl}_{3}\right) \delta 9.37$ (d, $J=7.4 \mathrm{~Hz}$, $1 \mathrm{H}), 7.89(\mathrm{~s}, 2 \mathrm{H}), 7.82(\mathrm{~s}, 1 \mathrm{H}), 7.71-7.63(\mathrm{~m}, 4 \mathrm{H}), 7.05(\mathrm{~d}, J=$ $8.6 \mathrm{~Hz}, 2 \mathrm{H}), 3.91(\mathrm{~s}, 3 \mathrm{H}), 3.27(\mathrm{~s}, 2 \mathrm{H}), 2.91(\mathrm{~s}, 2 \mathrm{H}), 2.02(\mathrm{~s}, 2 \mathrm{H}), 1.80$ $(\mathrm{s}, 2 \mathrm{H}) .{ }^{13} \mathrm{C} \mathrm{NMR}\left(101 \mathrm{MHz}, \mathrm{CDCl}_{3}\right) \delta 159.54,142.11,132.99$, $130.85,129.04,127.43,127.41,126.91,126.60,124.94,120.53$, 113.46, 55.38, 29.13, 26.20, 22.89, 22.55. HRMS (ESI): $m / z$ called for $\mathrm{C}_{24} \mathrm{H}_{21} \mathrm{NO}[\mathrm{M}+\mathrm{H}]^{+}$, 340.1696; found, 340.1708.
6-Fluoro-4-butyl-2-phenylquinoline (4bh). Yield, 91\%; white solid; mp 245-246 ${ }^{\circ} \mathrm{C}$; Rf 0.43 (petroleum ether/ethyl acetate = 10 : 1); IR (KBr): 3070, 2951, 2922, 1592, 1491, $1453 \mathrm{~cm}^{-1} ;{ }^{1} \mathrm{H}$ NMR $\left(400 \mathrm{MHz}, \mathrm{CDCl}_{3}\right) \delta 7.96(\mathrm{dd}, J=7.5,1.7 \mathrm{~Hz}, 2 \mathrm{H}), 7.46(\mathrm{~s}$, $2 \mathrm{H}), 7.16$ (d, $J=4.8 \mathrm{~Hz}, 2 \mathrm{H}), 7.08(\mathrm{~s}, 2 \mathrm{H}), 5.95(\mathrm{~s}, 1 \mathrm{H}), 2.37$ (s, 2H), 1.52 (s, 2H), 1.32 (s, 2H), $0.86(\mathrm{~s}, 3 \mathrm{H}) .{ }^{13} \mathrm{C}$ NMR (101 MHz, $\left.\mathrm{CDCl}_{3}\right) \delta 188.92,167.07,162.06,159.61,140.10,134.50,134.47$, $130.86,128.25,127.38,127.30,127.04,116.10,92.83,31.90$, $30.34,22.34,13.63$. HRMS (ESI): $m / z$ called for $\mathrm{C}_{19} \mathrm{H}_{18} \mathrm{FN}[\mathrm{M}+$ $\mathrm{H}]^{+}, 280.1455$; found, 280.1457 .

6-Chloro-4-butyl-2-phenylquinoline (4bi). Yield, 92\%; white solid; mp 237-238 ${ }^{\circ} \mathrm{C}$; Rf 0.45 (petroleum ether/ethyl acetate $=$ 10 : 1); IR (KBr): 3071, 2953, 2924, 1593, 1491, $1452 \mathrm{~cm}^{-1} ;{ }^{1} \mathrm{H}$ NMR (400 MHz, $\left.\mathrm{CDCl}_{3}\right) \delta 7.97(\mathrm{~d}, J=1.3 \mathrm{~Hz}, 2 \mathrm{H}), 7.47(\mathrm{~s}, 2 \mathrm{H})$, $7.36(\mathrm{~s}, 2 \mathrm{H}), 7.13(\mathrm{~s}, 2 \mathrm{H}), 5.97(\mathrm{~s}, 1 \mathrm{H}), 2.41(\mathrm{~s}, 2 \mathrm{H}), 1.53(\mathrm{~s}, 2 \mathrm{H})$, $1.34(\mathrm{~s}, 2 \mathrm{H}), 0.87(\mathrm{~s}, 3 \mathrm{H}) .{ }^{13} \mathrm{C}$ NMR $\left(101 \mathrm{MHz}, \mathrm{CDCl}_{3}\right) \delta 189.04$, 166.39, 139.99, 137.17, 131.43, 130.98, 129.30, 128.28, 127.07, 126.42, 93.37, 31.96, 30.33, 22.35, 13.68. HRMS (ESI): $\mathrm{m} / z$ called for $\mathrm{C}_{19} \mathrm{H}_{18} \mathrm{ClN}[\mathrm{M}+\mathrm{H}]^{+}$, 296.1107; found, 296.1109.

6-Bromo-4-butyl-2-phenylquinoline (4bj). Yield, 92\%; white solid; mp 240-241 ${ }^{\circ} \mathrm{C}$; Rf 0.47 (petroleum ether/ethyl acetate $=$ 10 : 1); IR (KBr): 3073, 2954, 2925, 1597, 1495, $1451 \mathrm{~cm}^{-1} ;{ }^{1} \mathrm{H}$ NMR (400 MHz, $\left.\mathrm{CDCl}_{3}\right) \delta 7.94(\mathrm{dd}, J=7.9,1.6 \mathrm{~Hz}, 2 \mathrm{H}), 7.50(\mathrm{~s}$, $4 \mathrm{H}), 7.09(\mathrm{~s}, 2 \mathrm{H}), 5.96(\mathrm{~s}, 1 \mathrm{H}), 2.42(\mathrm{~d}, J=8.0 \mathrm{~Hz}, 2 \mathrm{H}), 1.53(\mathrm{~d}, J=$ $7.5 \mathrm{~Hz}, 2 \mathrm{H}), 1.34$ (d, $J=7.5 \mathrm{~Hz}, 2 \mathrm{H}), 0.88$ (s, 3H). ${ }^{13} \mathrm{C}$ NMR (101 $\left.\mathrm{MHz}, \mathrm{CDCl}_{3}\right) \delta 189.12,166.30,139.96,137.68,132.28,130.98$, 128.28, 127.05, 126.74, 119.23, 93.45, 31.97, 30.34, 22.35, 13.67. HRMS (ESI): $m / z$ called for $\mathrm{C}_{19} \mathrm{H}_{18} \mathrm{BrN}[\mathrm{M}+\mathrm{H}]^{+}, 340.0696$; found, 340.0693 .

6-Iodo-4-butyl-2-phenylquinoline (4bk). Yield, 94\%; white solid; mp 245-246 ${ }^{\circ} \mathrm{C}$; Rf 0.51 (petroleum ether/ethyl acetate = 10 : 1); IR (KBr): 3075, 2959, 2928, 1599, 1495, $1453 \mathrm{~cm}^{-1} ;{ }^{1} \mathrm{H}$ NMR (400 MHz, $\left.\mathrm{CDCl}_{3}\right) \delta 7.98-7.90(\mathrm{~m}, 2 \mathrm{H}), 7.71(\mathrm{~d}, J=8.5 \mathrm{~Hz}$, $2 \mathrm{H}), 7.47(\mathrm{~s}, 2 \mathrm{H}), 6.97(\mathrm{~s}, 2 \mathrm{H}), 5.96(\mathrm{~s}, 1 \mathrm{H}), 2.44(\mathrm{~s}, 2 \mathrm{H}), 1.55(\mathrm{~s}$, $2 \mathrm{H}), 1.35$ (d, $J=7.5 \mathrm{~Hz}, 2 \mathrm{H}), 0.89$ (s, 3H). ${ }^{13} \mathrm{C}$ NMR (101 MHz, $\left.\mathrm{CDCl}_{3}\right) \delta 189.13,166.17,139.95,138.39,138.24,130.99,128.27$, 127.05, 126.90, 93.55, 90.04, 31.98, 30.34, 22.35, 13.67. HRMS (ESI): $m / z$ called for $\mathrm{C}_{19} \mathrm{H}_{18} \mathrm{IN}[\mathrm{M}+\mathrm{H}]^{+}, 388.0533$; found, 388.0537.

2,4-Diphenylquinoline (4bl). Yield, 90\%; white solid; mp 243-245 ${ }^{\circ} \mathrm{C}$; Rf 0.53 (petroleum ether/ethyl acetate $=10: 1$ ); IR (KBr): 3055, 3028, 2920, 1589, 1546, 1488, $1444 \mathrm{~cm}^{-1} ;{ }^{1} \mathrm{H}$ NMR $\left(400 \mathrm{MHz}, \mathrm{CDCl}_{3}\right) \delta 8.29(\mathrm{~d}, J=8.4 \mathrm{~Hz}, 1 \mathrm{H}), 8.23(\mathrm{~d}, J=7.3 \mathrm{~Hz}$, $2 \mathrm{H}), 7.93(\mathrm{~d}, J=8.3 \mathrm{~Hz}, 1 \mathrm{H}), 7.85(\mathrm{~s}, 1 \mathrm{H}), 7.75(\mathrm{~s}, 1 \mathrm{H}), 7.58(\mathrm{~d}, J=$ $1.7 \mathrm{~Hz}, 7 \mathrm{H}), 7.51-7.46(\mathrm{~m}, 2 \mathrm{H}) .{ }^{13} \mathrm{C} \mathrm{NMR}$ (101 MHz, $\mathrm{CDCl}_{3}$ ) $\delta 156.87,149.15,148.83,139.66,138.41,130.14,129.55,129.49$, 129.32, 128.81, 128.58, 128.38, 127.58, 126.31, 125.77, 125.62, 119.33. HRMS (ESI): $m / z$ called for $\mathrm{C}_{21} \mathrm{H}_{15} \mathrm{~N}[\mathrm{M}+\mathrm{H}]^{+}, 282.1277$; found, 282.1279.

6-Methyl-2,4-diphenylquinoline (4bm). Yield, 91\%; white solid; mp 244-247 ${ }^{\circ} \mathrm{C}$; Rf 0.52 (petroleum ether/ethyl acetate = 10 : 1); IR (KBr): 3054, 2915, 1588, 1544, 1488, $1449 \mathrm{~cm}^{-1} ;{ }^{1} \mathrm{H}$ NMR (400 MHz, $\left.\mathrm{CDCl}_{3}\right) \delta 8.26(\mathrm{~s}, 1 \mathrm{H}), 7.99(\mathrm{~s}, 2 \mathrm{H}), 7.71(\mathrm{~s}, 1 \mathrm{H})$, $7.41(\mathrm{~s}, 6 \mathrm{H}), 6.94(\mathrm{~s}, 2 \mathrm{H}), 6.72(\mathrm{~d}, J=7.5 \mathrm{~Hz}, 2 \mathrm{H}), 6.09(\mathrm{~s}, 1 \mathrm{H})$, $2.26(\mathrm{~s}, 3 \mathrm{H}) .{ }^{13} \mathrm{C} \mathrm{NMR}\left(101 \mathrm{MHz}, \mathrm{CDCl}_{3}\right) \delta 189.40,161.72$, 139.95, 136.78, 135.90, 134.10, 133.85, 133.05, 131.17, 130.78, 
129.56, 129.29, 128.48, 128.32, 127.20, 123.19, 96.54, 20.76. HRMS (ESI): $m / z$ called for $\mathrm{C}_{22} \mathrm{H}_{17} \mathrm{~N}[\mathrm{M}+\mathrm{H}]^{+}, 296.1443$; found, 295.1445.

6-Methoxy-4-ethyl-2-propylquinoline(4bn). Yield, $\quad 90 \%$; yellow oil; mp 241-243 ${ }^{\circ} \mathrm{C}$; Rf 0.55 (petroleum ether/ethyl acetate $=10: 1)$; IR (KBr): 3052, 2913, 1586, 1542, 1487, 1448 $\mathrm{cm}^{-1} ;{ }^{1} \mathrm{H}$ NMR $\left(400 \mathrm{MHz}, \mathrm{CDCl}_{3}\right) \delta 7.82(\mathrm{~d}, J=9.1 \mathrm{~Hz}, 1 \mathrm{H}), 7.66$ $(\mathrm{s}, 1 \mathrm{H}), 7.18(\mathrm{~d}, J=2.6 \mathrm{~Hz}, 1 \mathrm{H}), 6.91(\mathrm{~d}, J=2.4 \mathrm{~Hz}, 1 \mathrm{H}), 3.80$ (s, $3 \mathrm{H}), 2.83(\mathrm{~s}, 2 \mathrm{H}), 2.71(\mathrm{~s}, 2 \mathrm{H}), 1.74(\mathrm{~s}, 2 \mathrm{H}), 1.23(\mathrm{~s}, 3 \mathrm{H}), 0.97(\mathrm{~s}$, 3H). ${ }^{13} \mathrm{C}$ NMR $\left(101 \mathrm{MHz}, \mathrm{CDCl}_{3}\right) \delta 158.32,156.13,141.50$, 134.59, 131.87, 128.91, 127.14, 119.73, 103.68, 54.41, 36.54, $24.17,21.87,13.45,13.31$.

\section{Acknowledgements}

This work was supported by the grant from National Natural Science Foundation of China (21571121, 21271124, and 21446014), and the Fundamental Research Funds for the Central Universities (No. GK201302015, No. GK201501005) for financial support, the 111 Project (B14041), the Program for Chang jiang Scholars and Innovative Research Team in University (IRT_14R33), the Project Supported by Natural Science Basic Research Plan in Shaanxi Province of China (Program No. 2015JQ2056).

\section{Notes and references}

1 (a) G. Jiang and B. List, Angew. Chem., Int. Ed., 2011, 50, 9471-9474; (b) R. De Vreese and M. D'hooghe, Beilstein J. Org. Chem., 2012, 8, 398-402.

2 J. Li, L. L. Lin, B. W. Hu, X. J. Lian, G. Wang, X. H. Liu and X. F. Feng, Angew. Chem., Int. Ed., 2016, 55, 6075-6078.

3 B. D. Robertson, R. E. M. Brooner and R. A. Widenhoefer, Chem.-Eur. J., 2015, 21, 5714-5717.

4 S. Zhang, Z. L. Xu, J. Jia, C. H. Tung and Z. H. Xu, Chem. Commun., 2014, 50, 12084-12087.

5 G. B. Dong, P. Teo, Z. K. Wickens and R. H. Grubbs, Science, 2011, 333, 1609-1612.

6 S. Dhiman, U. K. Mishra and S. Ramasastry, Angew. Chem., Int. Ed., 2016, 55, 7737-7741.

7 (a) Z. Y. Han, H. Xiao, X. H. Chen and L. Z. Gong, J. Am. Chem. Soc., 2009, 131, 9182-9183; (b) C. Wang, Z. Y. Han, H. W. Luo and L. Z. Gong, Org. Lett., 2010, 12, 2266-2269; (c) Z. Y. Han, D. F. Chen, Y. Y. Wang, R. Guo, P. S. Wang, C. Wang and L. Z. Gong, J. Am. Chem. Soc., 2012, 134, 6532-6535; (d) J. Mo, D. Eom, E. Lee and P. H. Lee, Org. Lett., 2012, 14, 3684-3687; (e) H. Wu, Y. P. He and L. Z. Gong, Org. Lett., 2013, 15, 460-463; (f) D. Qian and J. L. Zhang, Chem.-Eur. J., 2013, 19, 6984-6988; $(g)$ Y. Horino, Y. Takahashi, Y. Nakashima and H. Abe, RSC $A d v$. , 2014, 4, 6215-6218; $(h)$ X. Wu, M. L. Li and P. S. Wang, J. Org. Chem., 2014, 79, 419-425; (i) S. Dhiman and S. S. V. Ramasastry, Org. Lett., 2015, 17, 5116-5119; (j) Y. N. Gao, F. C. Shi, Q. Xu and M. Shi, Chem.-Eur. J., 2016, 22, 6803-6807; (k) F. Zhao, N. Li, Y. F. Zhu and Z. Y. Han, Org. Lett., 2016, 18, 1506-1509.
8 (a) M. Terada and Y. Toda, Angew. Chem., Int. Ed., 2012, 51, 2093-2097; (b) Z. Y. Cao, Y. L. Zhao and J. Zhou, Chem. Commun., 2016, 52, 2537-2540; (c) Y. L. Zhao, Z. Y. Cao, X. P. Zeng, J. M. Shi, Y. H. Yu and J. Zhou, Chem. Commun., 2016, 52, 3943-3946.

9 G. X. Jiang and B. List, Adv. Synth. Catal., 2011, 353, 16671670.

10 H. Zhang, L. Zhu, S. Z. Wang and Z. J. Yao, J. Org. Chem., 2014, 79, 7063-7074.

11 (a) K. Sorimachi and M. Terada, J. Am. Chem. Soc., 2008, 130, 14452-14453; (b) Q. A. Chen, D. S. Wang, Y. G. Zhou, Y. Duan, H. J. Fan, Y. Yang and Z. Zhang, J. Am. Chem. Soc., 2011, 133, 6126-6129.

12 (a) H. Wu, Y. P. He and L. Z. Gong, Adv. Synth. Catal., 2012, 354, 975-980; (b) D. F. Chen, P. Y. Wu and L. Z. Gong, Org. Lett., 2013, 15, 3958-3961; (c) D. F. Chen, F. Zhao, Y. Hu and L. Z. Gong, Angew. Chem., Int. Ed., 2014, 53, 1076310767; (d) L. Deiana, Y. Jiang, C. P. Nieto, S. Afewerki, C. Pradillos, O. Verho, C. Tai, E. V. Johnston and A. Córdova, Angew. Chem., Int. Ed., 2014, 53, 3447-3451; (e) D. F. Chen, Z. Y. Han, X. L. Zhou and L. Z. Gong, Acc. Chem. Res., 2014, 47, 2365-2377; $(f)$ X. P. Yin, X. P. Zeng, Y. L. Liu, F. M. Liao, J. S. Yu, F. Zhou and J. Zhou, Angew. Chem., Int. Ed., 2014, 53, 13740-13745; (g) T. Suzuki, Ismiyarto, Y. Ishizaka, D. Y. Zhou, K. Asano and H. Sasai, Org. Lett., 2015, 17, 5176-5179; (h) X. L. Lian, J. Meng and Z. Y. Han, Org. Lett., 2016, 18, 4270-4273; (i) C. C. Pattillo, I. I. Strambeanu, P. Calleja, N. A. Vermeulen, T. Mizuno and M. C. White, J. Am. Chem. Soc., 2016, 138, 1265-1272; (j) M. Lesieur, Y. D. Bidal, F. Lazreg, F. Nahra and C. S. J. Cazin, ChemCatChem, 2015, 7, 2108-2112.

13 H. Yeom, Y. Lee, J. Jeong, E. So, S. Hwang, J. E. Lee, S. S. Lee and S. Shin, Angew. Chem., Int. Ed., 2010, 49, 16111614.

14 (a) N. G. Kozlov and L. I. Basalaeva, Russ. J. Org. Chem., 2009, 45, 587-590; (b) N. G. Kozlov and L. I. Basalaeva, Russ. J. Org. Chem., 2001, 71, 250-256.

15 X. S. Wang, Q. Li, J. R. Wu, Y. L. Li, C. S. Yao and S. J. Tu, Synthesis, 2008, 12, 1902-1910.

16 F. H. Xiao, W. Chen, Y. F. Liao and G. J. Deng, Org. Biomol. Chem., 2012, 10, 8593-8596.

17 W. Wei, J. W. Wen, D. S. Yang, X. J. Sun, J. M. You, Y. R. Suo and H. Wang, Tetrahedron, 2013, 69, 10747-10751.

18 X. F. Xu, W. M. Liu, Z. Q. Wang, Y. Q. Feng, Y. L. Yan and X. Zhang, Tetrahedron Lett., 2016, 57, 226-229.

19 (a) Y. Wu, C. Chen, G. Jia, X. Y. Zhu, H. M. Sun, G. F. Zhang, W. Q. Zhang and Z. W. Gao, Chem.-Eur. J., 2014, 20, 85308535; (b) X. Y. Zhu, C. Chen, B. X. Yu, G. F. Zhang, W. Q. Zhang and Z. W. Gao, Chem. Lett., 2014, 43, 18321834; (c) Y. Wu, X. Wang, Y. L. Luo, J. Wang, Y. J. Jian, H. M. Sun, G. F. Zhang, W. Q. Zhang and Z. W. Gao, RSC Adv., 2016, 6, 15298-15303; (d) X. Wang, Z. H. Wang, G. F. Zhang, W. Q. Zhang, Y. Wu and Z. W. Gao, Eur. J. Org. Chem., 2016, 3, 502-507; (e) Y. L. Luo, Y. Wu, Y. Y. Wang, H. M. Sun, Z. Y. Xie, W. Q. Zhang and Z. W. Gao, RSC Adv., 2016, 6, 66074-66077. 
20 M. Daigle, W. H. Bi, M. A. Legare, J. F. Morin and F. G. Fontaine, Inorg. Chem., 2015, 54, 5547-5555.

21 (a) D. Zhan, T. B. Li, H. D. Wei, W. Weng, K. Ghandi and Q. L. Zeng, RSC Adv., 2013, 3, 9325-9329; (b) R. Jalil, W. Voelter and M. Saeed, Tetrahedron Lett., 2004, 45, 3475-
3476; (c) I. E. Marko, P. R. Giles, M. Tsukazaki, S. M. Brown and C. J. Urch, Science, 1996, 274, 2044-2046; (d) S. Velusamy and T. Punniyamurthy, Tetrahedron Lett., 2003, 44, 8955-8957. 